2013

\title{
Using the Income Tax System as Your Hedge Counterparty
}

Timothy Edgar

Osgoode Hall Law School of York University, tedgar@osgoode.yorku.ca

Amir Aghdaei

Source Publication:

Australian Tax Forum. Volume 28, Issue 2 (2013), p. 317-376.

Follow this and additional works at: https://digitalcommons.osgoode.yorku.ca/scholarly_works cc) (1) $(9)$

This work is licensed under a Creative Commons Attribution-Noncommercial-No Derivative Works 4.0 License.

\section{Recommended Citation}

Edgar, Timothy, and Amir Aghdaei. "Using the Income Tax System as Your Hedge Counterparty." Australian Tax Forum 28.2 (2013): 317-376.

This Article is brought to you for free and open access by the Faculty Scholarship at Osgoode Digital Commons. It has been accepted for inclusion in Articles \& Book Chapters by an authorized administrator of Osgoode Digital Commons. 


\section{Using the income tax system as your hedge counterparty}

\section{Tim Edgar ${ }^{\star}$ and Amir Aghdaei**}

\section{Abstract}

A strain of the academic literature on taxation and risk taking emphasises the income effect and consequent transfer of risk to government through the income tax system in the presence of scaling of risky positions. The policy implications of this literature have been explored in considerable detail, although the practical significance for tax policymakers is ambiguous given the tax and non-tax constraints on scaling under the personal income tax. In contrast, fragmentary transactional evidence suggests that scaling of risky positions may have its most practical application in the context of corporate hedging transactions where many of the same tax and non-tax constraints do not apply. In fact, risk-transfer transactions in this very different context have been the subject of some recent attention by tax policymakers and tax administrators.

This paper explores the case for, and design of, a loss limitation intended to address the transfer of risk to government that otherwise is the result of hedged positions that are scaled to provide imperfectly offsetting pre-tax cash flows but perfectly (or near perfectly) offsetting after-tax cash flows. Although the case for such a limitation extends broadly to the entire range of such transactions, perceptions of costliness

\section{Acknowledgements}

The authors would like to thank Ben Alarie, Ed Kleinbard, Mike Kobetsky, and Leonard Nicita for comments on an earlier draft. An anonymous referee also provided helpful suggestions.

* Faculty of Law, Osgoode Hall Law School, York University and Faculty of Law, University of Sydney.

** LLM Candidate, University of Sydney.

This paper was accepted for publication on 25 February 2013. 
associated with the identification exercise, as well as perceptions of a negative impact on the decision to hedge, may lead to a more narrowly focused loss limitation patterned on legislation recently adopted by UK Inland Revenue. For the much more limited subset of risk-transfer transactions that are entered into for the purpose of providing a tax benefit, narrowly construed, general anti-tax avoidance rules and/or doctrines can provide an effective response. An example of this type of transaction is the asymmetric swap that is the subject of a taxation determination released by the Australian Taxation Office (ATO).

\section{Introduction}

In Taxation Determination TD 2010/12, ${ }^{1}$ the Australian Taxation Office (ATO) ruled that the general anti-avoidance rule in Part IVA of the Income Tax Assessment Act 1936 (ITAA 1936) can apply to an asymmetric swap scheme. These schemes, implemented by a number of Australian banks, received some attention in the popular press ${ }^{2}$ when the ATO first released Draft Taxation Determination TD 2009/D12, ${ }^{3}$ the predecessor to TD 2010/12. But the asymmetric swap that is the subject of this taxation determination is only one particular example of a broader set of transactions structured to transfer market risk to government through the income tax system. In fact, we understand that the Canada Revenue Agency (CRA) and the US Internal Revenue Service (IRS) are both currently examining similar transactions under audit. It is perhaps not surprising, therefore, that the Organisation for Economic Co-operation and Development (OECD) has also recently released a report highlighting the revenue threat from these transactions and canvassing possible responses. ${ }^{4}$ Such transactions are sometimes referred to as "after-tax hedging" or "over-hedging"/"under-hedging."

1 ATO, Taxation Determination TD 2010/12, "Income tax: can Part IVA of the Income Tax Assessment Act 1936 apply to an asymmetric swap scheme?" 28 April 2010.

2 See, for example, Richard Gluyas, "ATO Targets Banks' Swap Deals" The Australian, 7 November 2009. See also Ben Butler and Eric Johnston, “MacBank’s \$250m Tax Perk at Risk" Sydney Morning Herald, 11 April 2011.

3 ATO, Taxation Determination TD 2009/D12, "Income tax: can Part IVA of the Income Tax Assessment Act 1936 apply to an asymmetric swap scheme?” 14 October 2009.

4 OECD, Aggressive Tax Planning based on After-Tax Hedging (Paris: OECD, March 2013), at 3 and 7 (suggesting that hundreds of millions of USD revenue is at risk because of aggressive tax planning transactions based on after-tax hedging, with member countries identifying a number of multi-billion USD transactions). See also OECD, Corporate Loss Utilisation through Aggressive Tax Planning (Paris: OECD, August 2011), at 51-52 (describing certain after-tax hedging transactions intended to transfer losses from low-tax to high-tax jurisdictions). There is no mention of the subject of after-tax hedging in the discussion paper, recently released by Australian Treasury, on proposed amendments to the taxation of financial arrangements (TOFA) tax hedging rules in subdivision 230-E of the Income Tax Assessment Act, 1997 (ITAA 1997). See Australian Treasury Department, Improving the Operation of the Tax Hedging Provisions (Canberra: Commonwealth of Australia, Discussion Paper, February 2012). But see also Australian Treasury Department, Budget Measures 2013-14 - Part 1: Revenue Measures 
But to better convey the associated policy problem, we use the term "risk-transfer transactions" to describe these transactions. Although this term could also include transactions that transfer price risk through the market, we use the conventional term "hedge transaction" to distinguish them from those transactions that are the focus of this article.

In contrast with the ATO's reliance on Part IVA, UK Inland Revenue has recently targeted a subset of risk-transfer transactions (referred to as "risk-transfer schemes") with the application of a loss limitation. ${ }^{5}$ Although the focus of this legislative response is a broader set of transactions than the asymmetric swap considered in TD 2010/12, the ability to use government as an involuntary hedge counterparty through the income tax system is not limited to either the kinds of transactions that are the focus of the ATO taxation determination or the narrowly targeted loss limitation adopted in the United Kingdom. An income tax environment characterised by fixed asymmetric tax rates and non-binding loss limitations permits such risk transfer through scaling of the magnitude of pre-tax positions in a manner that provides imperfectly offsetting pre-tax cash flows but an effective after-tax hedge (that is, perfectly, or near perfectly, offsetting after-tax gain and loss). In short, with asymmetric tax rates, non-binding loss limitations and scaling of offsetting long and short positions, government can be made to bear the entirety of the relevant market risk reflected in the net tax liability associated with the offsetting positions.

There is surprisingly very little tax literature on scaling of positions in a hedge context. With the exception of the recent OECD report, noted above, ${ }^{6}$ what literature that does exist tends to be technical in its focus and ignores any associated policy problem. ${ }^{7}$ We emphasise that a generalised ability for corporate taxpayers to use the income tax system as their involuntary hedge counterparty presents a policy problem that requires an income-tax based response, preferably in the form of a loss limitation applicable to risk-transfer transactions generally and not just the subset of such transactions that are the focus of the UK legislative response. We suggest that a broad loss limitation applicable to risk-transfer transactions generally is preferable, primarily because of the entirely random incidence that is the result of the conditions required to facilitate such transactions. These conditions provide absolutely no normatively compelling rationale that would justify an acceptance of risk-transfer transactions by policymakers.

Ideally, the kind of broad loss limitation we propose would be combined with a hedge tax accounting regime, which may mute, to some extent at least, the substitution of risk transfer through the income tax system for risk transfer through the market.

(Paper 2) (Canberra: Commonwealth of Australia, 14 May 2013), at 34-35 (indicating pending amendments to the Offshore Banking Unit (OBU) regime to address unspecified integrity issues, which could extend to risk-transfer transactions effected through OBUs).

5 UK Finance Act 2010, section 46 and schedule 16 enacting Part 21A, sections 937A to 937O, of the Corporation Tax Act 2010 applicable to accounting periods beginning on or after 1 April 2010.

6 Aggressive Tax Planning based on After-Tax Hedging, supra note 4.

7 See, for example, Michael Feder, "After-Tax Hedging" (2010) 126 Tax Notes 1613 (describing circumstances in which income tax liabilities can be used to hedge risk). 
However, such a regime tends to be limited to the provision of symmetric timing and character recognition of gain and loss associated with offsetting pre-tax positions; it also tends to be less than comprehensive in failing to apply in a cross-border context, and in some cases is elective. ${ }^{8}$ As a result, one of the conditions required for the implementation of risk-transfer transactions - fixed asymmetric tax rates - holds for a broad range of corporate taxpayers, including financial institutions subject to mark-to-market recognition of gain or loss on non-capital account for traded assets and derivative instruments. ${ }^{9}$ A broad loss limitation is arguably required, therefore, because of the incompleteness of application of hedge tax accounting regimes, leaving a range of corporate taxpayers with an effective option to transfer risk through the income tax system rather than the market. The same loss limitation rule is also required in the absence of a hedge tax accounting regime, since taxpayers retain the same option in this legislative environment.

Despite the policy case for the adoption of a broad loss limitation, perceived compliance and administrative costs associated with the identification of a wide set of problematic transactions, as well as perceptions of a negative impact on the decision to hedge risk, ${ }^{10}$ may lead tax administrators and policymakers to distinguish:

- $\quad$ risk-transfer transactions that do not provide a financial benefit other than the transfer of risk;

8 The hedge tax accounting regime in ITAA 1997, subdivision 230-E reflects these features. Because it affects only timing and character of the recognition of gain and loss when taxpayers elect to have it apply, the Commissioner's discretion to treat offsetting positions as a hedge in the absence of a designation by the taxpayer would not disturb the effect of scaling in the presence of asymmetric tax rates. See ITAA 1997, section 230-345 (permitting the Commissioner, under certain conditions, to make a determination that the requirements of a hedge are met). The US hedge tax accounting regime providing character matching of gain and loss includes a "failed hedge rule," which ensures that a taxpayer may not avoid non-capital treatment by failing to identify transactions that are clearly hedge transactions. In the absence of a reasonable basis for failing to identify a hedge transaction, gain (but not loss) may be treated as ordinary income. See Internal Revenue Code (IRC) Reg. section 1221-2(f)(2)(iii); and Edward D. Kleinbard and Suzanne F. Greenberg, "Business Hedges After Arkansas Best" (1988) 43 Tax Law Review 393.

9 See, in this respect, Edward D. Kleinbard and Thomas L. Evans, "The Role of Mark-to-Market Accounting in a Realization-Based Tax System” (1997) 75 Taxes: The Tax Magazine 788 (characterising the application of mark-to-market reporting to the inventory of traders or dealers in securities as a substitute for a hedge accounting regime); and the elective financial reports method in ITAA 1997, subdivision 230-F and/or the elective fair value method in ITAA 1997, subdivision 230-C.

10 See, HM Revenue and Customs, "Technical Note on Overhedging and Underhedging," 10 August 2009, at 5 ("The Government recognises that there will be situations where groups are seeking to undertake commercial hedging transactions not covered by the present tax neutral hedging provisions. Where such situations arise there is no intention to prevent groups from undertaking overhedging or underhedging transactions where this is the only realistic way to provide an effective post tax hedge of the risk in question."). See also Aggressive Tax Planning based on After-Tax Hedging, supra note 4, at 35 (suggesting that there is a policy-relevant distinction between acceptable and unacceptable after-tax hedging). 
- risk-transfer transactions that provide a financial benefit other than the transfer of risk or a tax benefit; and

- risk-transfer transactions that provide a tax benefit.

Costliness of the identification exercise is particularly severe in a cross-border context, which commonly provides asymmetric tax rates necessary for scaling of offsetting positions and the consequent transfer of risk through the income tax system. Where a hedge tax accounting regime provides symmetric tax treatment for domestic transactions, the same identification exercise may not be as severe; yet tax policymakers may be willing to tolerate a range of risk-transfer transactions on an apparent empirical assumption that their implementation is limited. The same tolerance by policymakers, perhaps based on the same empirical assumption, is evident in those jurisdictions where a hedge tax accounting regime has not been adopted.

To the extent that risk-transfer transactions have been the subject of any response by tax policymakers and tax administrators, the apparent focus is what appears, intuitively at least, to be the more egregious transactions involving the transfer of risk through the income tax system and the provision of an additional financial advantage or a tax benefit. For the former type of risk-transfer transaction, a narrow loss limitation along the lines of that adopted in the United Kingdom is defensible. For the latter type of risk-transfer transaction, general anti-tax-avoidance rules or antitax-avoidance doctrines can provide an effective and defensible response. Indeed, because risk-transfer transactions of this type are nothing more than a particular example of tax-avoidance transactions, the effectiveness of the response depends on a characterisation of such transactions as carried out for the purpose of providing a tax benefit. Negating the transfer of risk to government through the income tax system is an entirely incidental effect of the application of general anti-tax-avoidance rules and/or doctrines.

Part two begins with a description of three representative risk-transfer transactions illustrating, at a general level, the shared features of such transactions. Part three follows with an articulation of the policy problem that is common to risk-transfer transactions. This part draws on the academic literature on taxation and risk taking which, despite a different focus, highlights the fact that the generalised policy problem presented by risk-transfer transactions is not unique to the subset of such transactions that, to date, have been the limited target of tax policymakers and tax administrators. Part four explores the design of a loss limitation applicable to risk-transfer transactions generally. The suggested design features are contrasted with the UK loss limitation, which targets the narrower range of risk-transfer transactions that provide a financial benefit other than a tax benefit and the transfer of risk through the income tax system. Part five concludes with a discussion of the application of general anti-tax-avoidance rules and/or doctrines to the even narrower range of risk-transfer transactions that are entered into to provide a tax benefit. The reasoning in TD 2010/12 is critiqued as an example of the kind of conceptual and factual difficulties of application that arise in this context. 


\section{Illustrative Risk-Transfer Transactions}

A risk-transfer transaction is designed to substitute for another transaction in which a taxpayer would otherwise:

- $\quad$ hedge market risk on a pre-tax basis by entering into short and long positions ${ }^{11}$ with offsetting pre-tax cash flows; or

- $\quad$ assume the market risk associated with an unhedged short or long position.

In the former instance, symmetric treatment of the offsetting short and long positions ensures that no net tax is payable. In the latter instance, gain or loss is recognised at the relevant tax rate and government shares the risk associated with the unhedged position in proportion to that rate.

As hedge transaction substitutes, risk-transfer transactions share four features. First, they are structured to split offsetting short and long positions such that the two positions are treated differently. Second, the magnitude of the offsetting positions are adjusted or scaled such that the pre-tax cash flows offset imperfectly. Third, scaling ensures that the after-tax cash flows offset perfectly once gain and loss is subject to the different treatment or, alternatively, that the market risk associated with an unhedged position is eliminated. Fourth, government effectively assumes the market risk reflected in the net tax liability associated with the imperfect pre-tax offset. In the absence of adjustment of offsetting short and long positions to account for different tax rates, market risk would be borne by market participants, with government sharing that risk as a function of the relevant tax rates.

Each of these features of risk-transfer transactions is illustrated below. The first two transactions are foreign-currency hedges described in a technical note released by UK Inland Revenue in August 2009 in advance of the introduction of legislation intended to address these and other similar transactions. ${ }^{12}$ The third example is an asymmetric swap, which is the subject of TD 2010/12. ${ }^{13}$

11 An investor is "long in an asset" if he or she owns the asset or has the right or obligation to purchase it. In that case, the investor benefits if the asset appreciates in value and loses if the asset depreciates. An investor is "short in an asset" if he or she has sold the asset or has the right or obligation to sell in the future. In that case, the investor benefits from any depreciation in value of the asset and loses if the asset appreciates.

12 Technical Note, supra note 10. See also Feder, supra note 7; and Aggressive Tax Planning based on After-Tax Hedging, supra note 4, at 18-19.

13 See also Aggressive Tax Planning based on After-Tax Hedging, supra note 4, at 24-27. 


\section{A Foreign-Currency Hedging}

\section{Example 1}

Aco and Bco are members of the same corporate Group X and subject to a 28 percent tax rate. Aco invests $100 \mathrm{~m}$ sterling (GBP) in yen-denominated (JPY) shares of a subsidiary, Subco. Group X would like to eliminate exchange rate risk attributable to depreciation of the JPY against GBP while also benefitting from yen interest rates that are significantly lower than GBP interest rates. To realize these goals, Bco borrows the JPY-equivalent of $139 \mathrm{~m} \mathrm{GBP}$.

\section{Figure 1}

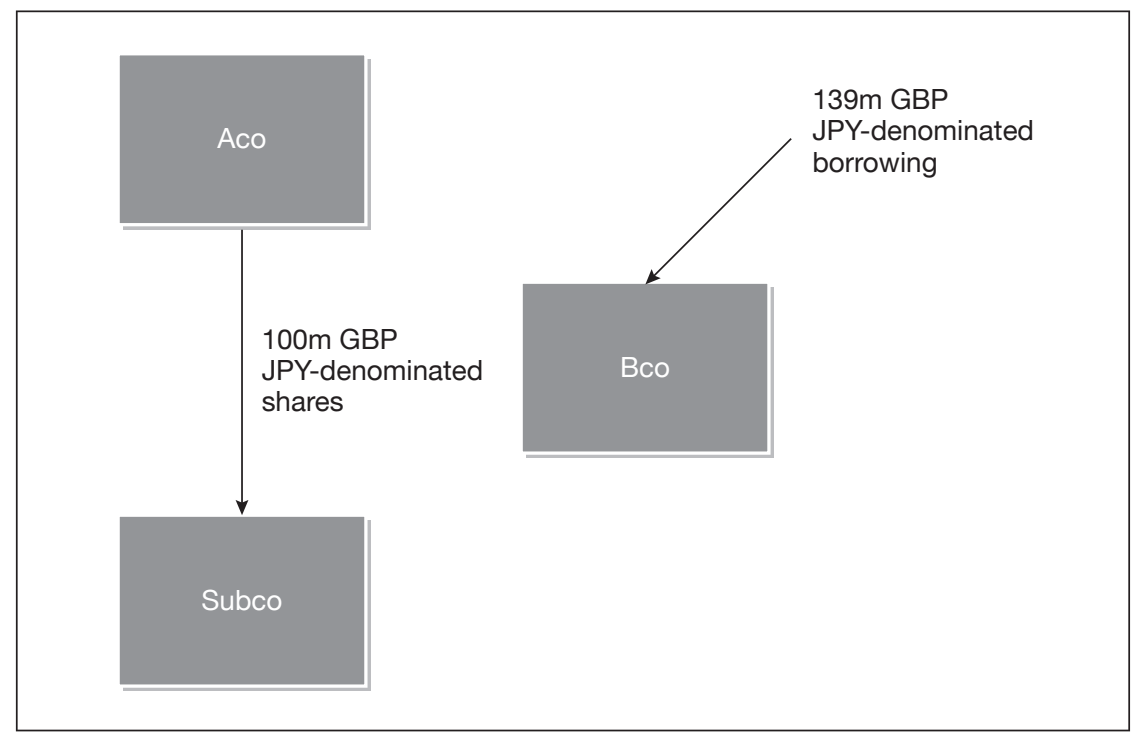

The hedge in example 1 is structured to provide asymmetric tax treatment of offsetting positions in the form of a timing mismatch. Foreign exchange gain or loss on the yendenominated shares of Subco held by Aco is brought to account on realisation, while offsetting loss or gain on the yen borrowing of Bco is brought to account annually on the retranslation basis. At an assumed corporate income tax rate of 28 percent, the yen borrowing is scaled up to the yen-equivalent of $139 \mathrm{~m}$ sterling $(100 \mathrm{~m} \times 100 \mathrm{~m} / 72 \mathrm{~m}=$ $139 \mathrm{~m}$ ) to provide a complete after-tax offset of unrealized gain or loss on the shares of Subco. The combination of the asymmetric tax treatment of the offsetting positions and the scaling up of the pre-tax borrowing allows Group X to borrow at the lower yen interest rate while eliminating exchange rate risk, which is effectively transferred to government through the income tax system. Under various changes in the sterling/ yen exchange rate, this result is summarised in table 1.1. 


\section{Table 1.1}

\begin{tabular}{|c|c|c|c|c|c|c|c|c|}
\hline GBP/JPY & $-30 \%$ & $-20 \%$ & $-10 \%$ & $-5 \%$ & $5 \%$ & $10 \%$ & $20 \%$ & $30 \%$ \\
\hline $\begin{array}{l}\text { Bco: FX gain/loss } \\
\text { on JPY borrowing }\end{array}$ & (41.70) & $(27.80)$ & (13.90) & (6.95) & 6.95 & 13.90 & 27.80 & 41.70 \\
\hline Tax payable & (11.70) & $(7.80)$ & (3.90) & (1.95) & 1.95 & 3.90 & 7.80 & 11.70 \\
\hline Net after-tax & (30) & (20) & (10) & (5) & 5 & 10 & 20 & 30 \\
\hline $\begin{array}{l}\text { Aco: FX gain/loss } \\
\text { Subco shares }\end{array}$ & 30 & 20 & 10 & 5 & (5) & (10) & (20) & (30) \\
\hline Tax payable & 0 & 0 & 0 & 0 & 0 & 0 & 0 & 0 \\
\hline Net after-tax & 30 & 20 & 10 & 5 & (5) & (10) & (20) & (30) \\
\hline $\begin{array}{l}\text { Consolidated } \\
\text { after-tax }\end{array}$ & 0 & 0 & 0 & 0 & 0 & 0 & 0 & 0 \\
\hline Net revenue & $(11.70)$ & $(7.80)$ & (3.90) & (1.95) & 1.95 & 3.90 & 7.80 & 11.70 \\
\hline
\end{tabular}

As an alternative to the hedge provided by the transaction in example 1, Aco could borrow yen equal to the sterling amount of its yen-denominated shares. Provided that foreign exchange gain or loss on the borrowing is taxed symmetrically with foreign exchange loss or gain on the yen-denominated shares, both the pre-tax and after-tax result would be no net gain or loss and no net revenue payable to government. This result is summarised in table 1.2.

Table 1.2

\begin{tabular}{l|c|c|c|c|c|c|c|c}
\hline GBP/JPY & $-\mathbf{3 0} \%$ & $-\mathbf{2 0} \%$ & $\mathbf{- 1 0} \%$ & $\mathbf{- 5 \%}$ & $\mathbf{5 \%}$ & $\mathbf{1 0 \%}$ & $\mathbf{2 0 \%}$ & $\mathbf{3 0 \%}$ \\
\hline $\begin{array}{l}\text { Aco: FX gain/ } \\
\begin{array}{l}\text { loss on shares } \\
\text { of Subco }\end{array}\end{array}$ & 30 & 20 & 10 & 5 & $(5)$ & $(10)$ & $(20)$ & $(30)$ \\
\hline $\begin{array}{l}\text { Aco: FX gain/ } \\
\text { loss on JPY } \\
\text { borrowing }\end{array}$ & $(30)$ & $(20)$ & $(10)$ & $(5)$ & 5 & 10 & 20 & 30 \\
\hline & 0 & 0 & 0 & 0 & 0 & 0 & 0 & 0 \\
\hline
\end{tabular}

\section{Example 2}

Bankco and Holdco are members of the same corporate Group Y and subject to a 28 percent tax rate. Holdco invests the JPY-equivalent of $100 \mathrm{~m}$ GBP in a limited partnership that invests in JPY-denominated bonds. Holdco then enters into: (i) 
a currency swap with Bankco with a notional principal amount of 100m GBP; and (ii) a forward currency contract with Bankco in the amount of 39m GBP. Under both the currency swap and forward currency contract, Holdco agrees to sell JPY for GBP at the current spot rate and also receives the difference between JPY and the higher GBP interest rates. Bankco offsets its positions with Holdco by entering into a mirror currency swap and forward contract in the market whereby it agrees to sell JPY for GBP.

\section{Figure 2}

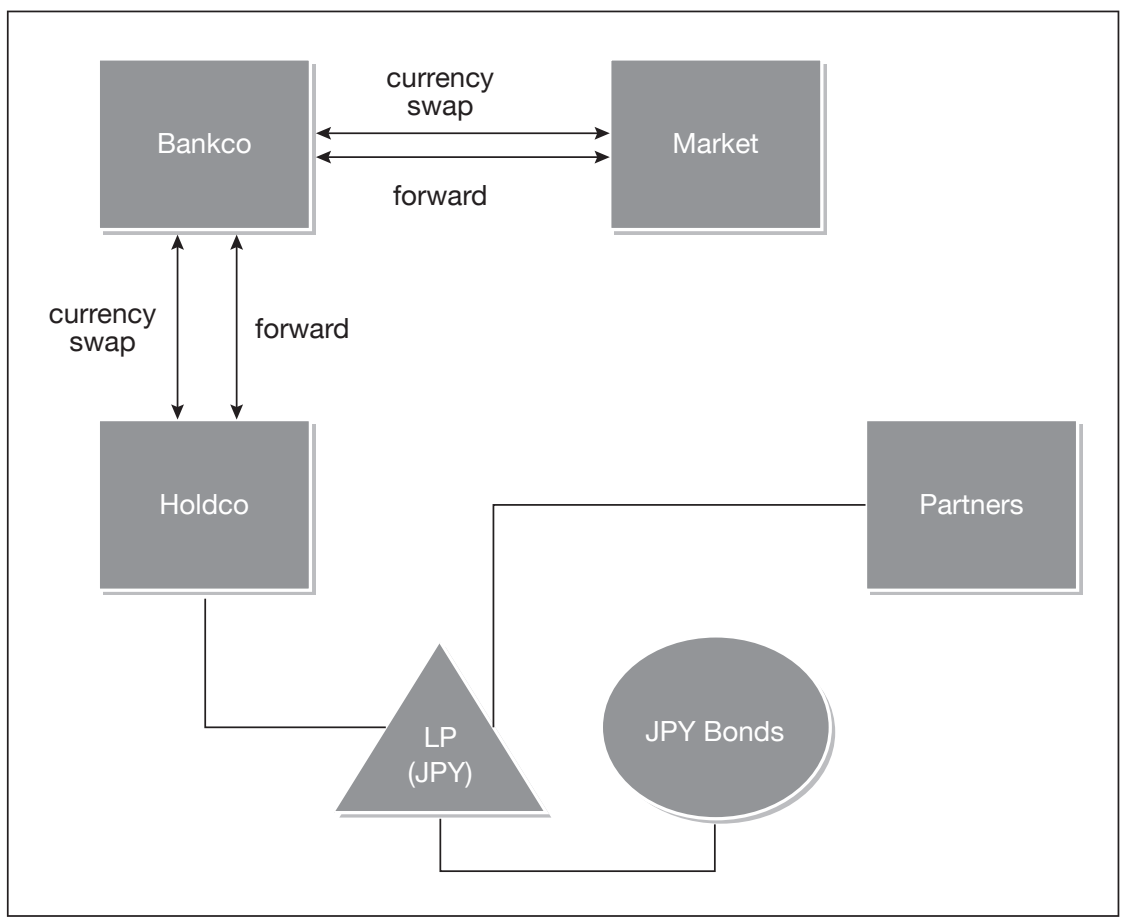

As with the transaction in example 1, the hedge in example 2 is structured to provide asymmetric tax treatment of offsetting positions in the form of a timing mismatch. Foreign exchange gain or loss on the yen-denominated bonds held by Holdco through its limited partnership interest is brought to account on realisation in the form of gain or loss allocated to Holdco. ${ }^{14}$ Offsetting loss or gain on the currency swap and the forward contract with Bankco is brought to account on the closing out of the contracts,

14 Technical Note, supra note 10, at 5 (indicating that JPY is the functional currency of the limited partnership so that any exchange gain or loss on the bonds will not be recognised). 
which will precede realisation on the bonds. ${ }^{15}$ At an assumed corporate income tax rate of 28 percent, the forward contract is used to scale up Holdco's foreign exchange position to the yen-equivalent of $139 \mathrm{~m}$ sterling $(100 \mathrm{~m} \times 100 \mathrm{~m} / 72 \mathrm{~m}=139 \mathrm{~m})$, which provides a complete after-tax offset of unrealised gain or loss on the yen-denominated bonds through the limited partnership interest. Under various changes in the sterling/ yen exchange rate, the after-tax position of Holdco is summarised in table 2.1.

\section{Table 2.1}

\begin{tabular}{l|c|c|c|c|c|c|c|c|c}
\hline GBP/JPY & $\mathbf{- 3 0} \%$ & $\mathbf{- 2 0} \%$ & $\mathbf{- 1 0} \%$ & $\mathbf{- 5} \%$ & $\mathbf{5} \%$ & $\mathbf{1 0} \%$ & $\mathbf{2 0} \%$ & $\mathbf{3 0} \%$ \\
\hline $\begin{array}{l}\text { Holdco: FX gain/ } \\
\text { loss currency swap }\end{array}$ & $(30)$ & $(20)$ & $(10)$ & $(5)$ & 5 & 10 & 20 & 30 \\
\hline Tax payable & $(8.40)$ & $(5.60)$ & $(2.80)$ & $(1.40)$ & 1.40 & 2.80 & 5.60 & 8.40 \\
\hline & \multicolumn{7}{|c}{} \\
\hline $\begin{array}{l}\text { Holdco: FX gain/ } \\
\text { loss forward }\end{array}$ & $(11.70)$ & $(7.80)$ & $(3.90)$ & $(1.95)$ & 1.95 & 3.90 & 7.80 & 11.70 \\
\hline \begin{tabular}{l} 
Tax payable \\
\hline
\end{tabular} & $(3.30)$ & $(2.20)$ & $(1.10)$ & $(0.55)$ & 0.55 & 1.10 & 2.20 & 3.30 \\
\hline & $(30)$ & $(20)$ & $(10)$ & $(5)$ & 5 & 10 & 20 & 30 \\
\hline \begin{tabular}{l} 
Net after-tax \\
\hline
\end{tabular} & 30 & 20 & 10 & 5 & $(5)$ & $(10)$ & $(20)$ & $(30)$ \\
\hline $\begin{array}{l}\text { Holdco: FX gain/ } \\
\text { loss JPY bond }\end{array}$ & 0 & 0 & 0 & 0 & 0 & 0 & 0 & 0 \\
\hline Tax payable & 30 & 20 & 10 & 5 & $(5)$ & $(10)$ & $(20)$ & $(30)$ \\
\hline Net after-tax &
\end{tabular}

Because of its mirror positions under the currency swap and forward with Holdco and the market, Bankco is perfectly hedged, both pre-tax and after-tax, and will realise no net gain or loss. This result is summarised in table 2.2.

15 See Technical Note, supra note 10, at 5 (indicating that Holdco is accounting under old UK GAAP and is treating the currency swap as a hedge of the limited partnership interest brought to account on realisation. The principal amount on the forward contract is treated as a hedge of the tax on the currency swap and is brought to account when the tax on the currency swap is brought to account). 


\section{Table 2.2}

\begin{tabular}{l|c|c|c|c|c|c|c|c}
\hline GBP/JPY & $\mathbf{- 3 0} \%$ & $\mathbf{- 2 0} \%$ & $\mathbf{- 1 0} \%$ & $\mathbf{- 5 \%}$ & $\mathbf{5 \%}$ & $\mathbf{1 0} \%$ & $\mathbf{2 0} \%$ & $\mathbf{3 0} \%$ \\
$\begin{array}{l}\text { Bankco: FX } \\
\text { gain/loss with } \\
\text { Holdco }\end{array}$ & 30 & 20 & 10 & 5 & $(5)$ & $(10)$ & $(20)$ & $(30)$ \\
\hline $\begin{array}{l}\text { Bankco: FX } \\
\text { gain/loss with } \\
\text { market }\end{array}$ & $(30)$ & $(20)$ & $(10)$ & $(5)$ & 5 & 10 & 20 & 30 \\
\hline Net after-tax & 0 & 0 & 0 & 0 & 0 & 0 & 0 & 0 \\
\hline
\end{tabular}

The hedge in example 2 differs from the hedge in example 1 in the form of the benefit realised by the corporate group. The combination of the asymmetric tax treatment of the offsetting positions and the scaling up of the pre-tax foreign exchange position allows Group $\mathrm{Y}$ to earn a return greater than the sterling interest rate while eliminating exchange rate risk. This result is realised because of the off-market pricing of the currency swap and the forward. In particular, the exchange rate under both contracts is the spot exchange rate rather than a forward exchange rate that, in theory, reflects the interest rate differential of the two currencies. ${ }^{16}$ To bring the contracts onmarket, Bankco will receive, under its contracts with the market, the present value of the interest rate differential between the stronger yen and the weaker sterling. Bankco must pay the same amount to Holdco under its off-market currency swap and forward contract with Holdco, which can invest the prepayment at the sterling interest rate. Holdco will thereby earn the lower interest rate on the yen-denominated bonds, plus the sterling interest rate on the prepayment under the currency swap and forward contract, while eliminating its exchange rate risk. The total exceeds what would otherwise be interest earned on a sterling-denominated bond in the amount of $100 \mathrm{~m}$ or, alternatively, interest plus expected foreign exchange gain on a yen-denominated bond where unexpected gain or loss is hedged by Holdco selling yen forward at the forward exchange rate.

As with the hedge in example 1, exchange rate risk otherwise borne by Group Y is effectively transferred to government through the income tax system. This result is summarised in table 2.3 .

16 The arbitrage pricing relationship, known as "covered interest-rate parity", holds that the difference between forward and spot exchange rates for two currencies must equal the difference between interest rates for borrowings/loans in the same currencies. This equivalence ensures that a borrowing/loan in a weak currency yields the same return as an equivalent borrowing/ loan in a stronger currency. Covered interest-rate parity is expressed as:

$\mathrm{E} f / \mathrm{E} s=(1+\mathrm{i} r) /(1+\mathrm{i} d)$

where $\mathrm{E} s$ is the spot exchange rate for two currencies; $\mathrm{E} f$ is the forward exchange rate; ir is the interest rate for the foreign currency; and $\mathrm{i} d$ is the interest rate for the domestic currency. 
Table 2.3

\begin{tabular}{l|c|c|c|c|c|c|c|c}
\hline GBP/JPY & $\mathbf{- 3 0} \%$ & $\mathbf{- 2 0} \%$ & $\mathbf{- 1 0} \%$ & $\mathbf{- 5} \%$ & $\mathbf{5 \%}$ & $\mathbf{1 0} \%$ & $\mathbf{2 0} \%$ & $\mathbf{3 0} \%$ \\
\hline $\begin{array}{l}\text { Net revenue from } \\
\begin{array}{l}\text { FX gain/loss } \\
\text { Holdco }\end{array}\end{array}$ & $(11.70)$ & $(7.80)$ & $(3.90)$ & $(1.95)$ & 1.95 & 3.90 & 7.80 & 11.70 \\
\hline $\begin{array}{l}\text { Consolidated } \\
\text { after-tax }\end{array}$ & 0 & 0 & 0 & 0 & 0 & 0 & 0 & 0 \\
\hline
\end{tabular}

\section{B Asymmetric Swap}

\section{Example 3}

Non-resident bank and resident bank are unrelated. To eliminate exposure associated with a $\$ 150 \mathrm{~m}$ long position on an equity index, non-resident bank enters into two swaps with resident bank. One swap ("the short swap") is entered into with the offshore banking unit (OBU) of resident bank, which is subject to a 10 percent tax rate. The short swap requires: (i) non-resident bank to pay the percentage decrease in value of a $\$ 525 \mathrm{~m}$ notional amount of the index; and (ii) resident bank to pay the percentage increase in value of the same notional principal. The other swap ("the long swap") is entered into with resident bank's domestic banking unit (DBU), which is subject to a 30 percent tax rate. The long swap requires: (i) non-resident bank to pay the percentage increase in value of a $\$ 675 \mathrm{~m}$ notional amount of the index; and (ii) resident bank to pay the percentage decrease in value of the same notional principal.

\section{Figure 3}

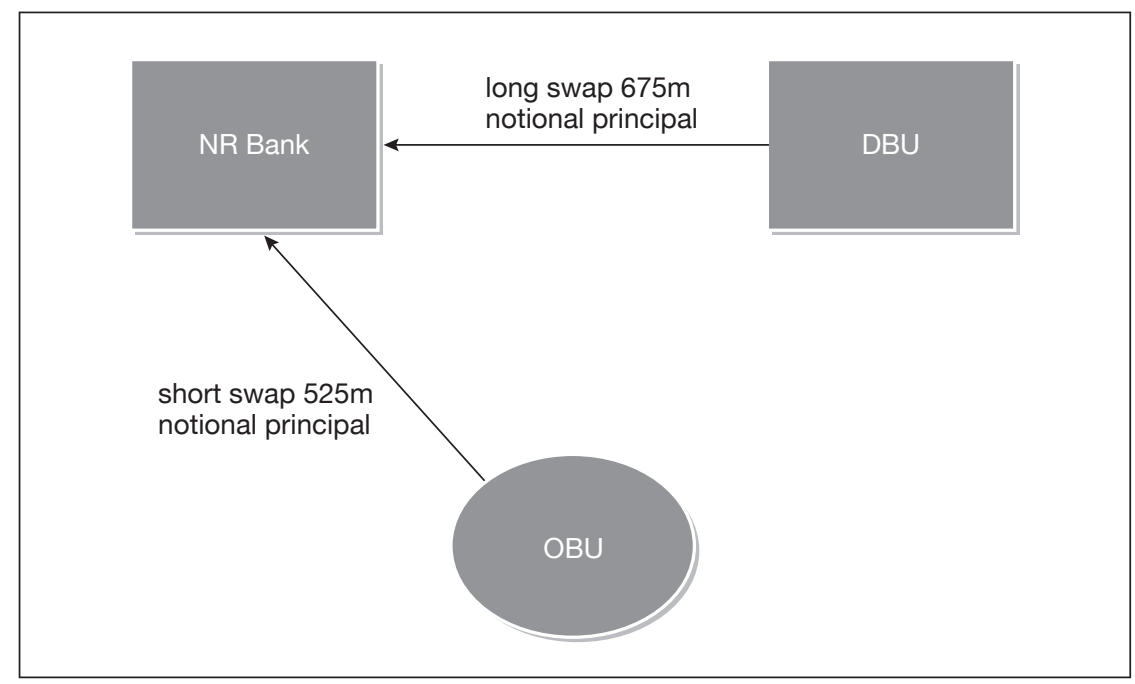


Similar to the foreign-currency hedges in examples 1 and 2, the asymmetric swap in example 3 is structured to provide asymmetric tax treatment of offsetting positions, but using different statutory tax rates rather than a timing mismatch. Gain or loss on the short swap is brought to account at a 10 percent tax rate by the OBU of resident bank, while offsetting loss or gain on the long swap is brought to account at a 30 percent tax rate by resident bank's DBU. To provide the required hedge of non-resident bank's long equity index position of $\$ 150 \mathrm{~m}$, the notional principal amounts of the short and long swap positions are set to vary by this amount, but also incorporating a tax-rate scaling of the relevant amounts. Scaling of the positions ensures that after-tax gain on one position for resident bank is offset by after-tax loss on the other position. In short, the combination of the asymmetric tax treatment of the offsetting positions and the scaling up of the short swap position $(472.50 \mathrm{~m} / .9=525 \mathrm{~m})$ and long swap position $(472.50 \mathrm{~m} / .7=675 \mathrm{~m})$ allows resident bank to provide the required hedge to non-resident bank for a fee while transferring the net exposure to the equity index to government through the income tax system. Under various changes in the value of the equity index, this result is summarised in table 3.1 (after-tax positions of OBU and resident bank's DBU, as well as government's revenue position). The position of non-resident bank is summarised in table 3.2.

\section{Table 3.1}

\begin{tabular}{|c|c|c|c|c|c|c|c|c|}
\hline $\begin{array}{l}\text { Rise/fall } \\
\text { value of } \\
\text { equity } \\
\text { index }\end{array}$ & $-100 \%$ & $-75 \%$ & $-50 \%$ & $-25 \%$ & $25 \%$ & $50 \%$ & $75 \%$ & $100 \%$ \\
\hline $\begin{array}{l}\text { Short swap: } \\
\text { OBU }\end{array}$ & 525 & 393.75 & 262.50 & 131.25 & (131.25) & (262.50) & (393.75) & (525) \\
\hline Tax payable & 52.50 & 39.38 & 26.25 & 13.13 & (13.13) & $(26.25)$ & (39.38) & $(52.50)$ \\
\hline After-tax & 472.50 & 354.37 & 236.25 & 118.12 & $(118.12)$ & (236.25) & (354.37) & (472.50) \\
\hline $\begin{array}{l}\text { Long swap: } \\
\text { DBU }\end{array}$ & (675) & (506.25) & (337.50) & (168.75) & 168.75 & 337.50 & 506.25 & 675 \\
\hline Tax payable & $(202.50)$ & (151.88) & (101.25) & (50.63) & 50.63 & 101.25 & 151.88 & 202.50 \\
\hline After-tax & $(472.50)$ & (354.37) & (236.25) & (118.12) & 118.12 & 236.25 & 354.37 & 472.50 \\
\hline $\begin{array}{l}\text { Consolidated } \\
\text { after-tax }\end{array}$ & 0 & 0 & 0 & 0 & 0 & 0 & 0 & 0 \\
\hline Net revenue & (150) & $(112.50)$ & (75) & $(37.50)$ & 37.50 & 75 & 112.50 & 150 \\
\hline
\end{tabular}


Table 3.2

\begin{tabular}{l|c|c|c|c|c|c|c|c}
\hline $\begin{array}{l}\text { Rise/fall } \\
\text { value of } \\
\text { equity index }\end{array}$ & $\mathbf{- 1 0 0 \%}$ & $\mathbf{- 7 5 \%}$ & $\mathbf{- 5 0 \%}$ & $\mathbf{- 2 5 \%}$ & $\mathbf{2 5 \%}$ & $\mathbf{5 0 \%}$ & $\mathbf{7 5 \%}$ & $\mathbf{1 0 0 \%}$ \\
$\begin{array}{l}\text { Long equity } \\
\text { index }\end{array}$ & $(150)$ & $(112.50)$ & $(75)$ & $(37.50)$ & 37.50 & 75 & 112.50 & 150 \\
\hline $\begin{array}{l}\text { Long equity } \\
\text { index swap }\end{array}$ & $(525)$ & $(393.75)$ & $(262.50)$ & $(131.25)$ & 131.25 & 262.50 & 393.75 & 525 \\
\hline $\begin{array}{l}\text { Short equity } \\
\text { index swap }\end{array}$ & 675 & 506.25 & 337.50 & 168.75 & $(168.75)$ & $(337.50)$ & $(506.25)$ & $(675)$ \\
\hline Net position & 0 & 0 & 0 & 0 & 0 & 0 & 0 & 0 \\
\hline
\end{tabular}

An alternative transaction to the asymmetric swap would involve non-resident bank entering into an offsetting short position with resident bank's DBU. For example, nonresident bank could enter into an equity index swap with a notional principal amount of $\$ 150 \mathrm{~m}$, whereby it would pay resident bank's DBU any increase in the value of the index and it would receive any decrease in value. As summarised in table 3.3, this would leave non-resident bank with no net exposure to the index.

\section{Table 3.3}

\begin{tabular}{l|c|c|c|c|c|c|c|c}
\hline $\begin{array}{l}\text { Rise/fall value of } \\
\text { equity index }\end{array}$ & $\mathbf{- 1 0 0 \%}$ & $\mathbf{- 7 5 \%}$ & $\mathbf{- 5 0 \%}$ & $\mathbf{- 2 5 \%}$ & $\mathbf{2 5 \%}$ & $\mathbf{5 0} \%$ & $\mathbf{7 5 \%}$ & $\mathbf{1 0 0} \%$ \\
\hline Long equity index & $(150)$ & $(112.50)$ & $(75)$ & $(37.50)$ & 37.50 & 75 & 112.50 & 150 \\
\hline $\begin{array}{l}\text { Short equity } \\
\text { index swap }\end{array}$ & 150 & 112.50 & 75 & 37.50 & $(37.50)$ & $(75)$ & $(112.50)$ & $(150)$ \\
\hline Net position & 0 & 0 & 0 & 0 & 0 & 0 & 0 & 0 \\
\hline
\end{tabular}

Resident bank's DBU would assume a long position on the equity index of $\$ 150 \mathrm{~m}$ and would otherwise have to hedge this position in the market for a fee charged to non-resident bank. If the long equity index position is left unhedged, government's revenue position would reflect a sharing of the associated risk with resident bank's $\mathrm{DBU}$ at the 30 percent tax rate applicable to it. This result is summarised in table 3.4. If the same position is hedged by the DBU, resident bank would realise no net gain or loss, and there would be no net revenue payable to government.

\section{Table 3.4}

\begin{tabular}{l|c|c|c|c|c|c|c|c}
\hline $\begin{array}{l}\text { Rise/fall value of } \\
\text { equity index }\end{array}$ & $\mathbf{- 1 0 0 \%}$ & $\mathbf{- 7 5} \%$ & $\mathbf{- 5 0 \%}$ & $\mathbf{- 2 5 \%}$ & $\mathbf{2 5 \%}$ & $\mathbf{5 0} \%$ & $\mathbf{7 5 \%}$ & $\mathbf{1 0 0 \%}$ \\
$\begin{array}{l}\text { Long equity index } \\
\text { swap }\end{array}$ & $(150)$ & $(112.50)$ & $(75)$ & $(37.50)$ & 37.50 & 75 & 112.50 & 150 \\
\hline Tax payable & $(45)$ & $(33.75)$ & $(22.50)$ & $(11.25)$ & 11.25 & 22.50 & 33.75 & 45 \\
\hline After-tax position & $(105)$ & $(78.75)$ & $(52.50)$ & $(26.25)$ & 26.25 & 52.50 & 78.75 & 105 \\
\hline
\end{tabular}




\section{Articulating the Policy Problem}

In the absence of a behavioural response, returns to risk under an income tax are shared by taxpayers and government, with the relevant shares determined as a function of the relevant tax rates. Risk-transfer transactions, such as those in examples 1 to 3 , alter this tax treatment by transferring all of the return associated with a risky position to government through the income tax system. In the 2009 UK budget, this distinction between risk sharing and risk transfer was highlighted as the policy problem presented by such transactions:

\footnotetext{
"The Government is aware of certain structured arrangements (often described as Overhedging or underhedging) which, although not normally undertaken for tax avoidance, involve fragmenting transactions across group companies to ensure the Exchequer bears the full economic risk to the group. The Government believes that the economic risks should be shared between the Exchequer and business as Parliament intended."17
}

Although the tax literature on hedging ignores the academic literature on taxation and risk taking, a deeper and more complete understanding of the policy implications of this distinction between risk sharing and risk transfer in the context of hedge transactions can be found in this academic literature; it suggests that the policy relevance of the distinction depends on the nature of the response to risk taking under symmetric and asymmetric tax rates and, more particularly, the effect of this different rate environment on speculative positions as well as hedge transactions, both in terms of the decision to enter into such transactions and the form that such transactions take. Depending on some empirical assumptions about the dimension of certain behavioural responses, a review of this literature reveals that the policy problem highlighted in the 2009 UK budget extends beyond the limited set of risktransfer transactions that are the focus of the UK loss limitation and the application of Part IVA in TD 2010/12; it includes scaling of unhedged or speculative positions as well as any transaction by which pre-tax offsetting positions are scaled such that the pre-tax cash flows offset imperfectly while the after-tax cash flows offset perfectly or near perfectly.

\section{A Risk Taking, Tax Rates and Scaling}

The academic literature on taxation and risk taking focuses on the effect of the income tax on the decision to take on risk and originates with the seminal article by Evsey Domar and Richard Musgrave published nearly 70 years ago. ${ }^{18}$ Their fundamental insight concerns the behavioural response to risk taking under asymmetric gain and loss tax rates that result from limitations on the use of losses. Using a simple model, with portfolio choice limited to an asset without default risk yielding no real return

17 HM Treasury, Budget 2009: Building Britain's Future (London: The Stationery Office, 22 April 2009), at para. 5.115.

18 Evsey Domar and Richard Musgrave, "Proportional Income Taxation and Risk Taking" (1944) 58 Quarterly Journal of Economics 388. 
and a risky asset in the sense that its payoff depends on a specified contingency, they illustrate that an income tax system with full loss offset has only an income effect and no substitution effect. In other words, symmetric treatment of gains and losses ensures that the after-tax gain/loss ratio is the same as the pre-tax ratio, and investors will determine the composition of their portfolios based on their taste for risk.

\section{Example 4}

Investor acquires a risky asset at a cost of $\$ 100$ and that has a 50 percent chance of paying $\$ 120$ or a 50 percent chance of paying $\$ 80$. The expected return is zero ([0.5 $\mathrm{x} \$ 20]-[0.5 \mathrm{x}(\$ 20)])$, which is consistent with the expected return on an alternative riskless asset available at a cost of $\$ 100$ and paying $\$ 100$ on maturity.

Assuming a 40 percent tax rate for illustrative purposes, the after-tax positive payoff on the risky asset in example 4 would be $\$ 12$, and the negative payoff would be $(\$ 12)$ provided that losses are fully refunded for income tax purposes at the relevant rate. Symmetric gain/loss tax rates thus ensure that government shares at the same tax rate in both gains and losses on the risky asset. In contrast, asymmetric treatment of losses and gains alters the after-tax gain/loss ratio as compared to the pre-tax ratio. For example, if losses are not recognised for income tax purposes while gains are taxed at 40 percent, the after-tax amount of the negative payoff on the risky asset in example 4 is the same as its pre-tax amount of $(\$ 20)$; yet the after-tax amount of the positive payoff is $\$ 12$. Under this particular asymmetric rate structure, government shares in gains at the 40 percent tax rate but does not share in losses, which may cause investors to substitute the riskless for the risky asset. These results, as well as those under a 40 percent gain tax rate and a 20 percent loss tax rate, are summarised in table 4 .

\section{Table 4}

\begin{tabular}{l|c|c|c|c|c|c} 
& $\begin{array}{c}\mathbf{4 0 \%} \\
\text { gain/ } \\
\text { loss tax } \\
\text { rate }\end{array}$ & $\begin{array}{c}\mathbf{4 0 \%} \\
\text { gain tax } \\
\text { rate/NIL } \\
\text { loss tax } \\
\text { rate }\end{array}$ & $\begin{array}{c}\mathbf{4 0 \%} \\
\text { gain tax } \\
\text { rate/20\% } \\
\text { loss tax } \\
\text { rate }\end{array}$ & \\
\hline Gain/loss & 20 & $(20)$ & 20 & $(20)$ & 20 & $(20)$ \\
\hline Tax payable & 8 & $(8)$ & 8 & 0 & 8 & $(4)$ \\
\hline Net after-tax & 12 & $(12)$ & 12 & $(20)$ & 12 & $(16)$ \\
\hline
\end{tabular}

One strain of the taxation and risk taking literature following Domar-Musgrave emphasises the dimensions of the substitution effect caused by asymmetric taxation of gains and losses. ${ }^{19} \mathrm{~A}$ subset of this strain of the literature refines the Domar-

19 The case for full loss refundability is based on Domar-Musgrave and the focus of their model on the substitution effect caused by asymmetric gain/loss tax rates attributable to binding loss limitations. This focus is apparent, for example, in Tax Review Panel, Australia's Future Tax System: Report to the Treasurer (Canberra: Australian Treasury Department, December 2009), at 174-76. 
Musgrave model by introducing different specifications of investor taste for risk. ${ }^{20}$ Another subset attempts to test empirically for the substitution effect under loss limitations which result in asymmetric taxation of gains and losses. ${ }^{21} \mathrm{~A}$ more recent strain of the taxation and risk taking literature emphasises, instead, the income effect under a proportional income tax with full loss offset. ${ }^{22}$ More particularly, as originally articulated by Kaplow, ${ }^{23}$ a tax environment characterised by symmetric gain/loss tax rates allows investors to eliminate the taxation of the return to risk bearing by scaling up risky asset positions to maintain the variance associated with desired pre-tax positions. In the presence of scaling, government continues to share in risky returns but additional risk is transferred through the income tax system.

\section{Example 5}

Investor acquires 1.66 units of risky asset at a cost of $\$ 166.67$ and that have a 50 percent chance of paying $\$ 200$ or a 50 percent chance of paying $\$ 133.33$. The expected return is zero $([0.5 \mathrm{x} \$ 33.33]-[0.5 \mathrm{x}(\$ 33.33)])$, which is consistent with the expected return on an alternative riskless asset available at a cost of $\$ 100$ and paying $\$ 100$ on maturity.

20 See, for example, Joseph E. Stiglitz, "The Effects of Income, Wealth, and Capital Gains Taxation on Risk Taking" (1969) 83 Quarterly Journal of Economics 263; and James Tobin, "Liquidity Preference as Behavior Towards Risk" (1958) 25 Review of Economic Studies 65.

21 See, for example, Julie Berry Cullen and Roger H. Gordon, “Taxes and Entrepreneurial RiskTaking: Theory and Evidence for the U.S." (2007) 91 Journal of Public Economics 1479 (finding that various tax-law features, including loss limitations and progressive personal rates, have collectively had large effects on the amount of entrepreneurial activity, but observing that the option to incorporate can encourage risk taking by providing favourable asymmetric rates where the corporate rate is lower than the personal rate); and Michael G. Cooper and Matthew J. Knittel, "The Implications of Tax Asymmetry for U.S. Corporations" (2010) 63 National Tax Journal 33 (finding for the period 1993-2004 that partial loss refundability disproportionately affects certain industries and younger firms).

22 See Joseph Bankman and Barbara H. Fried, "Winners and Losers in the Shift to a Consumption Tax" (1998) 86 Georgetown Law Journal 539; Joseph Bankman and Thomas Griffith, "Is the Debate Between an Income Tax and a Consumption Tax A Debate About Risk? Does it Matter?" (1992) 47 Tax Law Review 377; Alvin C. Warren, Jr., "How Much Capital Income Taxed Under an Income Tax Is Exempt Under a Cash Flow Tax?” (1996) 52 Tax Law Review 1; and David A. Weisbach, "The (Non) Taxation of Risk" (2004) 58 Tax Law Review 1. The model on which this literature is based is articulated in Louis Kaplow, "Taxation and Risk Taking: A General Equilibrium Perspective" (1994) 47 National Tax Journal 789. See also Jeremy I. Bulow and Lawrence H. Summers, "The Taxation of Risky Assets" (1984) 92 Journal of Political Economy 20; and Roger H. Gordon, "Taxation of Corporate Capital Income: Tax Revenues Versus Tax Distortions” (1985) 100 Quarterly Journal of Economics 1.

23 Kaplow, supra note 22. See also Thomas J. Brennan, "Certainty and Uncertainty in the Taxation of Risky Returns" (New York University School of Law Colloquium on Tax Policy and Public Finance, April 2009) (observing that symmetric taxation of the return to risky assets provides a tax payoff profile equivalent to that of a forward contract written on the underlying asset in an amount equal to the tax that can be eliminated by entering into an equal and opposite forward contract). 
By scaling up the amount invested in the risky asset in example 4 to account for taxation of both gain and loss at a rate of 40 percent, the investor in example 5 ensures that after-tax returns equal the desired returns in the absence of tax. That is, the riskreturn trade off desired by the investor in the absence of tax is maintained in the presence of taxation. The scaled amount is a function of the formula:

$x(1 / 1-t)$

where

$x=$ the desired position in the absence of scaling

$t=$ the tax rate applicable to the relevant position

With positive and negative pre-tax payoffs of $\$ 33.33$ and (\$33.33), respectively, the after-tax positive payoff subject to a 40 percent tax rate on the scaled-up investment in the risky asset would be $\$ 20$, and the negative payoff would be (\$20) where losses are fully refunded for income tax purposes at the same tax rate. As with example 4, symmetric gain/loss tax rates ensure that government shares at the same tax rate in both gains and losses on the risky asset. However, the investor in the risky asset in example 5 has increased government's risky revenue position from $\$ 8 /(\$ 8)$ to $\$ 13.33 /$ (\$13.33) by scaling up the amount invested, which provides an after-tax return equal to the desired pre-tax return of either $\$ 20$ or $(\$ 20)$ in the absence of the tax. Scaling of the investment thus ensures that there is no substitution effect but only an income effect that eliminates taxation of the risky asset for the investor while increasing the magnitude of the risky revenue stream for government.

Importantly, scaling has this result in an environment of symmetric gain/loss tax rates. Asymmetric gain and loss tax rates result in the risky asset being subject to tax despite the scaling up of the investment. Assuming, as with example 4, that losses are not recognised for income tax purposes while gains are taxed at 40 percent, the after-tax amount of the negative payoff on the risky asset in example 5 is the same as its pre-tax amount of (\$33.33); yet the after-tax amount of the positive payoff is $\$ 20$. The amount of the government share of gain is simply increased with the scaling of the investment. Where losses are not refunded, government does not share in the loss and captures an increased share of the gain. Where the loss tax rate is less than the gain tax rate, government also shares in the loss but at the lower rate. In effect, scaling in the presence of no loss offset means that the risky asset is subject to tax and government captures a positive revenue stream. Scaling in the presence of a positive loss tax rate that is less than the gain tax rate means that government realises a risky revenue stream, but the magnitude of this revenue stream is less than that in an environment of symmetric gain/loss tax rates. Risk is thereby transferred through the income tax system to government, but the transfer is incomplete because of an asymmetric sharing ratio that is a function of asymmetric gain/loss tax rates. These results are summarised in table 5. 
Table 5

\begin{tabular}{l|c|c|c|c|c|c} 
& $\begin{array}{c}\mathbf{4 0} \% \\
\text { gain/ } \\
\text { loss tax } \\
\text { rate }\end{array}$ & $\begin{array}{c}\mathbf{4 0 \%} \\
\text { gain tax } \\
\text { rate/NIL } \\
\text { loss tax } \\
\text { rate }\end{array}$ & & $\begin{array}{c}\mathbf{4 0 \%} \\
\text { gain tax } \\
\text { rate/20\% } \\
\text { loss tax } \\
\text { rate }\end{array}$ & \\
\hline Gain/loss & 33.33 & $(33.33)$ & 33.33 & $(33.33)$ & 33.33 & $(33.33)$ \\
\hline Tax payable & 13.33 & $(13.33)$ & 13.33 & 0 & 13.33 & $(6.67)$ \\
\hline Net after-tax & 20 & $(20)$ & 20 & $(33.33)$ & 20 & $(26.66)$ \\
\hline
\end{tabular}

\section{B Hedge Transactions, Tax Rates and Scaling}

Hedge transactions differ from those transactions that are the focus of the taxation and risk taking literature in the sense that the former are undertaken to eliminate risk associated with a long or short position, while the latter implicate the choice to take on risk by assuming an open or speculative long or short position in an asset with risky returns. But although it is unacknowledged, the conventional focus of the income tax treatment of hedge transactions is very much the same as that strain of the taxation and risk taking literature that emphasises the substitution effect under asymmetric gain/loss tax rates attributable to loss limitations. Indeed, hedge tax accounting regimes represent a particular application of the basic Domar-Musgrave insight.

\section{Example 6}

Investor is long a risky asset with a cost of $\$ 100$ and that has a 50 percent chance of paying $\$ 120$ or a 50 percent chance of paying $\$ 80$. To eliminate the risk associated with the contingent payoffs on this asset, investor enters into an offsetting contract with a cost of $\$ 100$ and that pays $\$ 80$ if the payoff on the risky asset is $\$ 120$ and $\$ 120$ if the payoff on the risky asset is $\$ 80$.

In the presence of asymmetric gain/loss tax rates, offsetting pre-tax positions, consisting of a hedge and an underlying transaction, can result in a net tax position, either positive or negative. Assume, for example, that gain or loss on the risky asset in example 6 is subject to a 20 percent tax rate while offsetting loss or gain on the hedge contract is subject to a 40 percent tax rate. If the risky asset pays $\$ 120$ and the hedge pays $\$ 80$, investor will realise a $\$ 16$ after-tax gain on the risky asset and a ( $\$ 12)$ aftertax loss on the hedge contract. The net after-tax result of the two offsetting positions for the hedged investor is a $\$ 4$ tax saving even though the pre-tax gain of $\$ 20$ on the risky asset is offset by a $(\$ 20)$ pre-tax loss on the hedge contract. If the risky asset pays $\$ 80$ and the hedge pays $\$ 120$, investor will realise a $\$ 12$ after-tax gain on the hedge contract and a (\$16) after-tax loss on the risky asset. The net after-tax result of the two offsetting positions for the hedged investor is a $\$ 4$ tax payment even though the pretax gain of $\$ 20$ on the hedge contract is offset by a $(\$ 20)$ pre-tax loss on the risky asset. 
The asymmetric gain and loss tax rates mean that government will either refund $\$ 4$ to investor or receive a $\$ 4$ tax payment, even though the offsetting positions provide no net pre-tax gain or loss. These results are summarised in table 6.1, as well as those where: (i) the gain/loss tax rate on the underlying is 40 percent and the gain/loss tax rate on the hedge is 20 percent; and (ii) the gain tax rate is 40 percent and the loss tax rate is zero.

\section{Table 6.1}

\begin{tabular}{|c|c|c|c|c|c|c|}
\hline & $\begin{array}{l}20 \% \text { gain/ } \\
\text { loss tax } \\
\text { rate on } \\
\text { underlying } \\
\text { and } 40 \% \\
\text { gain/loss } \\
\text { tax rate on } \\
\text { hedge }\end{array}$ & & $\begin{array}{l}\mathbf{4 0} \% \text { gain/ } \\
\text { loss tax } \\
\text { rate on } \\
\text { underlying } \\
\text { and } 20 \% \\
\text { gain/loss } \\
\text { tax rate on } \\
\text { hedge }\end{array}$ & & $\begin{array}{c}40 \% \text { gain } \\
\text { tax rate } \\
\text { and zero } \\
\text { loss tax } \\
\text { rate }\end{array}$ & \\
\hline $\begin{array}{l}\text { Gain/loss: } \\
\text { underlying }\end{array}$ & 20 & (20) & 20 & (20) & 20 & (20) \\
\hline $\begin{array}{l}\text { Tax payable: } \\
\text { underlying }\end{array}$ & 4 & (4) & 8 & (8) & 8 & 0 \\
\hline $\begin{array}{l}\text { After-tax: } \\
\text { underlying }\end{array}$ & 16 & (16) & 12 & (12) & 12 & (20) \\
\hline Gain/loss: hedge & (20) & 20 & (20) & 20 & (20) & 20 \\
\hline $\begin{array}{l}\text { Tax payable: } \\
\text { hedge }\end{array}$ & (8) & 8 & (4) & 4 & 0 & 8 \\
\hline After-tax: hedge & (12) & 12 & (16) & 16 & (20) & 12 \\
\hline $\begin{array}{l}\text { Net tax payable: } \\
\text { underlying and } \\
\text { hedge }\end{array}$ & (4) & 4 & 4 & (4) & 8 & 8 \\
\hline $\begin{array}{l}\text { Net after-tax: } \\
\text { underlying and } \\
\text { hedge }\end{array}$ & 4 & (4) & (4) & 4 & (8) & (8) \\
\hline $\begin{array}{l}\text { Net pre-tax: } \\
\text { underlying and } \\
\text { hedge }\end{array}$ & 0 & 0 & 0 & 0 & 0 & 0 \\
\hline
\end{tabular}


In addition to loss limitations, which can result in an effective zero loss tax rate, reduced recognition rates for capital gains and losses, ${ }^{24}$ as well as different timing rules for transactions on capital and non-capital account, ${ }^{25}$ can mean that the components of a hedged position (that is, the underlying position and the hedge) are subject to asymmetric taxation, with the after-tax result different from the pre-tax result. As with the strain of the taxation and risk-taking literature emphasising the substitution effect under loss limitations, much of the tax policy literature has emphasised the substitution effect for the choice to transfer risk under asymmetric taxation of an underlying transaction and a hedge. That is, taxing offsetting pre-tax payoffs as if they give rise to net gain or loss may cause taxpayers to forgo all or a portion of a hedged position with associated efficiency losses.

Hedge tax accounting regimes are intended to restore symmetric taxation of gain and loss on a hedged asset or liability and an offsetting hedge, usually by altering the treatment of the timing and character of the gain or loss on the latter consistent with the loss or gain on the former. In short, applying timing and character recognition for gain or loss on a hedge with reference to loss or gain on an underlying position ensures matching offsetting positions. By maintaining symmetry of tax treatment in these particular respects, adverse pricing effects that might otherwise inhibit efficient hedging strategies are avoided. ${ }^{26}$ It is probably accurate to say that, in principle at least, this form of integrated treatment, which is the basis for hedge tax accounting regimes, is regarded favourably in the tax literature. ${ }^{27}$ The results of the application of a hedge tax accounting regime providing symmetric taxation of the underlying and hedge in example 6 are summarised in table 6.2 .

24 See, for example, the discount capital gains rules in ITAA 1997, Division 115.

25 See, in this respect, examples 1 and 2. The results of a risk-transfer transaction focused on asymmetry of timing do not account for asymmetry of tax rates attributable to asymmetry of character.

26 See, for example, David M. Schizer, "Balance in the Taxation of Derivative Securities: An Agenda for Reform” (2004) 104 Columbia Law Review 1886, at 1914-15 (arguing that a hedge accounting regime is defensible because of the maintenance of symmetry of gain and loss recognition rates for offsetting positions).

27 The conventional view in the finance literature holds that hedging can increase the value of a firm by, in part, reducing taxes through the smoothing of taxable income. See, for example, JeanMarie Gagnon, Nabil Khoury, and Suzanne Landry, "The Tax Benefits of Hedging for Small and Medium-Sized Firms" (2010) 23 Journal of Small Business and Entrepreneurship 393; and John R. Graham and Clifford W. Smith, Jr., "Tax Incentives to Hedge" (1999) 54 Journal of Finance 2241 (exploring the extent to which firms facing convex tax functions hedge to reduce the volatility of taxable income). But see also John R. Graham and Daniel A. Rogers, "Do Firms Hedge in Response to Tax Incentives?" (2002) 57 Journal of Finance 815 (finding that firms hedge to increase debt capacity and its associated tax benefit). 
Table 6.2

\begin{tabular}{l|c|c} 
& $\begin{array}{c}\mathbf{2 0} \% \text { gain/loss tax } \\
\text { rate underlying } \\
\text { and hedge } \\
\text { contract }\end{array}$ & $(20)$ \\
\hline Gain/loss: underlying & 20 & $(8)$ \\
\hline Tax payable: underlying & 8 & $(12)$ \\
\hline After-tax: underlying & 12 & 20 \\
\hline Gain/loss: hedge & $(20)$ & 8 \\
\hline Tax payable: hedge & $(8)$ & 12 \\
\hline After-tax: hedge & $(12)$ & 0 \\
\hline Net tax payable: underlying and hedge & 0 & 0 \\
\hline Net after-tax: underlying and hedge & 0 & 0 \\
\hline Net pre-tax: underlying and hedge & 0 & \\
\hline
\end{tabular}

Risk-transfer transactions are based on the same fundamental insight as the strain of the taxation and risk taking literature emphasising the income effect and the elimination of the taxation of risky returns through scaling of a risky position. These transactions differ importantly, however, from the decision to take on risk and the elimination of the taxation of risky returns through scaling, which requires full loss offset and fixed symmetric gain/loss tax rates. As a form of hedge transaction, risktransfer transactions also require non-binding loss limitations (that is, losses on a position can be used in full to offset income taxable at the same rate as the gain tax rate on the position); but such transactions require fixed asymmetric gain/loss tax rates applicable to an underlying position and a related hedge. This, in turn, requires the inapplicability of a hedge tax accounting regime, or where applicable, its limited effect in the form of symmetric timing and character treatment. Under these necessary conditions, an underlying transaction and a hedge can be scaled such that pre-tax cash flows do not offset, but after-tax cash flows do offset and risky returns on the underlying are eliminated on an after-tax basis. The scaled positions required to realise an effective after-tax hedge can be generalised as a function of fixed asymmetric tax rates applicable to an underlying position and a hedge position: ${ }^{28}$ 
$r=1-t u / 1-t h$

where

$r=$ the hedge ratio

$t u=$ the tax rate on the underlying position

th $=$ the tax rate on the hedge position

\section{Example 7}

Investor is long a risky asset with a cost of $\$ 100$ and that has a 50 percent chance of paying $\$ 120$ or a 50 percent chance of paying $\$ 80$. Returns on the risky asset are subject to a 20 percent tax rate. To eliminate the risk associated with the contingent payoffs on this asset on an after-tax basis, investor enters into an offsetting contract with a cost of $\$ 133.33$ and that pays $\$ 106.67$ if the payoff on the risky asset is $\$ 120$ and $\$ 160$ if the payoff on the risky asset is $\$ 80$. Risky returns on the offsetting contract are subject to a 40 percent tax rate.

Unlike the investor in example 6, the investor in example 7 has scaled up the hedge to $\$ 133.33$ in the absence of a hedge tax accounting regime to provide an after-tax gain or loss that offsets after-tax loss or gain on the asymmetrically taxed underlying position with a cost of $\$ 100$. The after-tax result is thus consistent with that which would arise when the pre-tax cash flows on the hedge and underlying positions offset and are taxed symmetrically. If the risky asset pays $\$ 120$, the hedge will pay $\$ 106.67$, and investor will realise a $\$ 16$ after-tax gain on the risky asset and a (\$16) after-tax loss on the hedge contract. If the risky asset instead pays $\$ 80$ and the hedge pays $\$ 160$, investor will realise a (\$16) after-tax loss on the underlying position and a $\$ 16$ after-tax gain on the hedge contract. This scaling of the hedge does not eliminate, however, the effect of asymmetric tax rates for government, which provides an increased amount of loss relief or receives an increased tax payment that is a function of the scaled position. For example, in example 6 , the asymmetric gain and loss tax rates mean that government will either refund $\$ 4$ to investor or receive a $\$ 4$ tax payment even though the offsetting positions provide no net pre-tax gain or loss. These two results are increased to either a $\$ 6.67$ refund or a $\$ 6.67$ tax payment as a result of the scaled up hedge. In effect, the risky revenue stream is increased in magnitude by the scaled position, and risk is transferred to government in the same manner emphasised by the strain of the taxation and risk taking literature emphasising the income effect associated with scaling of speculative risky positions. Table 7 summarises the results of scaling the underlying and hedge in example 7 under different gain/loss tax rate assumptions and different hedge ratios. 


\section{Table 7}

\begin{tabular}{|c|c|c|c|c|c|c|}
\hline & & \begin{tabular}{|c|}
$20 \%$ gain/ \\
loss tax rate \\
on underlying \\
and $40 \%$ \\
gain/loss \\
tax rate on \\
hedge
\end{tabular} & $\begin{array}{c}40 \% \text { gain/ } \\
\text { loss tax rate } \\
\text { on underlying } \\
\text { and } 20 \% \\
\text { gain/loss tax } \\
\text { rate on hedge }\end{array}$ & & $\begin{array}{l}\text { zero tax } \\
\text { rate on } \\
\text { underlying } \\
\text { and } 40 \% \\
\text { tax rate on } \\
\text { hedge }\end{array}$ & \\
\hline Hedge ratio & 1.33 & & 0.75 & & 1.67 & \\
\hline $\begin{array}{l}\text { Gain/loss: } \\
\text { underlying }\end{array}$ & 20 & (20) & 20 & (20) & 20 & (20) \\
\hline $\begin{array}{l}\text { Tax payable: } \\
\text { underlying }\end{array}$ & 4 & (4) & 8 & (8) & 0 & 0 \\
\hline $\begin{array}{l}\text { After-tax: } \\
\text { underlying }\end{array}$ & 16 & (16) & 12 & (12) & 20 & (20) \\
\hline $\begin{array}{l}\text { Gain/loss: } \\
\text { hedge }\end{array}$ & (26.67) & 26.67 & (15) & 15 & (33.33) & 33.33 \\
\hline $\begin{array}{l}\text { Tax payable: } \\
\text { hedge }\end{array}$ & (10.67) & 10.67 & (3) & 3 & (13.33) & 13.33 \\
\hline $\begin{array}{l}\text { After-tax: } \\
\text { hedge }\end{array}$ & (16) & 16 & (12) & 12 & 20 & 20 \\
\hline $\begin{array}{l}\text { Net tax } \\
\text { payable: } \\
\text { underlying } \\
\text { and hedge }\end{array}$ & $(6.67)$ & 6.67 & 5 & (5) & (13.33) & 13.33 \\
\hline $\begin{array}{l}\text { Net after-tax: } \\
\text { underlying and } \\
\text { hedge }\end{array}$ & 0 & 0 & 0 & 0 & 0 & 0 \\
\hline $\begin{array}{l}\text { Net pre-tax: } \\
\text { underlying } \\
\text { and hedge }\end{array}$ & $(6.67)$ & 6.67 & 5 & (5) & (13.33) & 13.33 \\
\hline
\end{tabular}

\section{Example 8}

Investor is long a risky asset with a cost of $\$ 125$ and that has a 50 percent chance of paying $\$ 150$ or a 50 percent chance of paying $\$ 100$. Returns on the risky asset are subject to a 20 percent tax rate. To eliminate the risk associated with the contingent payoffs on this asset on an after-tax basis, investor enters into an offsetting contract with a cost of $\$ 166.67$ and that pays $\$ 133.33$ if the payoff on the risky asset is $\$ 150$ and $\$ 200$ if the payoff on the risky asset is $\$ 100$. Risky returns on the offsetting contract are subject to a 40 percent tax rate. 
Example 8 illustrates how it is also possible to scale both the underlying and hedge positions to provide offsetting after-tax cash flows that are equal to the desired offsetting pre-tax cash flows. Here again, each position must be scaled up as a function of the tax rate applicable to the position, with the required scaling expressed generally by the formula $x(1 / 1-t)$ noted above. At an assumed 20 percent tax rate applicable to the underlying, investor has scaled up this position from $\$ 100$ to $\$ 125$ and, at a 40 percent tax rate applicable to the hedge, has scaled up this position from $\$ 100$ to $\$ 166.67$. If the risky asset pays $\$ 150$, the hedge will pay $\$ 133.33$, and investor will realise a $\$ 20$ after-tax gain on the risky asset and a $(\$ 20)$ after-tax loss on the hedge. If the risky asset pays $\$ 100$ and the hedge pays $\$ 200$, investor will realise a $(\$ 20)$ after-tax loss on the underlying and a $\$ 20$ after-tax gain on the hedge. As compared to examples 6 and 7, the magnitude of the government's risky revenue position has been increased such that it will either refund $\$ 8.33$ to investor or receive a $\$ 8.33$ tax payment (rather than a $\$ 4$ refund or $\$ 4$ tax payment in example 6 and a $\$ 6.67$ refund or $\$ 6.67$ payment in example 7). These results are summarised in table 8 .

\section{Table 8}

\begin{tabular}{|c|c|c|}
\hline & \multicolumn{2}{|c|}{$\begin{array}{l}20 \% \text { gain/loss tax rate on underlying and } \\
40 \% \text { gain/loss tax rate on hedge contract }\end{array}$} \\
\hline Gain/loss: underlying & 25 & (25) \\
\hline Tax payable: underlying & 5 & (5) \\
\hline After-tax: underlying & 20 & (20) \\
\hline Gain/loss: hedge & (33.33) & 33.33 \\
\hline Tax payable: hedge & $(13.33)$ & 13.33 \\
\hline After-tax: hedge & (20) & 20 \\
\hline $\begin{array}{l}\text { Net tax payable: } \\
\text { underlying and hedge }\end{array}$ & (8.33) & 8.33 \\
\hline $\begin{array}{l}\text { Net after-tax: underlying } \\
\text { and hedge }\end{array}$ & 0 & 0 \\
\hline $\begin{array}{l}\text { Net pre-tax: underlying } \\
\text { and hedge }\end{array}$ & (8.33) & 8.33 \\
\hline
\end{tabular}

\section{Example 9}

Bankco assumes a long position with investor on a risky asset at a notional principal amount of $\$ 300$. At the same time, Bankco assumes a short position with investor on the same risky asset at a notional principal amount of $\$ 400$. Bankco's long position is subject to a 20 percent tax rate. The short position is subject to a 40 percent tax rate. 
As illustrated by example 9, the ability to scale offsetting positions to provide offsetting after-tax cash flows equal to the desired pre-tax cash flows means that offsetting positions can be adjusted such that government's risky revenue stream replicates the risk associated with an open or unhedged market position. This result is summarised in table 9 where it can be seen that, whatever the change in value of the long and short positions, the net tax payable of Bankco replicates the cash flows associated with an open or unhedged short position in respect of the risky asset with a notional principal value of $\$ 100$.

\section{Table 9}

\begin{tabular}{|c|c|c|c|c|c|c|c|c|}
\hline $\begin{array}{l}\text { Rise/fall value } \\
\text { of risky asset }\end{array}$ & $-100 \%$ & $-75 \%$ & $-50 \%$ & $-25 \%$ & $25 \%$ & $50 \%$ & $75 \%$ & $100 \%$ \\
\hline $\begin{array}{l}\text { Long position: } \\
\text { Bankco }\end{array}$ & (300) & (225) & $(150)$ & (75) & 75 & 150 & 225 & 300 \\
\hline Tax payable & (60) & (45) & (30) & (15) & 15 & 30 & 45 & 60 \\
\hline $\begin{array}{l}\text { After-tax: long } \\
\text { position }\end{array}$ & (240) & (180) & (120) & (60) & 60 & 120 & 180 & 240 \\
\hline $\begin{array}{l}\text { Short position: } \\
\text { Bankco }\end{array}$ & 400 & 300 & 200 & 100 & (100) & (200) & (300) & $(400)$ \\
\hline Tax payable & 160 & 120 & 80 & 40 & $(40)$ & (80) & (120) & (160) \\
\hline $\begin{array}{l}\text { After-tax: short } \\
\text { position }\end{array}$ & 240 & 180 & 120 & 60 & $(60)$ & (120) & $(180)$ & $(240)$ \\
\hline $\begin{array}{l}\text { Net tax payable: } \\
\text { Bankco }\end{array}$ & 100 & 75 & 50 & 25 & (25) & (50) & (75) & $(100)$ \\
\hline $\begin{array}{l}\text { Net after-tax } \\
\text { position: Bankco }\end{array}$ & 0 & 0 & 0 & 0 & 0 & 0 & 0 & 0 \\
\hline $\begin{array}{l}\text { Short position: } \\
\text { investor }\end{array}$ & 300 & 225 & 150 & 75 & (75) & (150) & (225) & $(300)$ \\
\hline $\begin{array}{l}\text { Long position: } \\
\text { investor }\end{array}$ & (400) & $(300)$ & $(200)$ & $(100)$ & 100 & 200 & 300 & 400 \\
\hline $\begin{array}{l}\text { Net position: } \\
\text { investor }\end{array}$ & (100) & (75) & (50) & (25) & 25 & 50 & 75 & 100 \\
\hline
\end{tabular}

With appropriate scaling of offsetting long and short positions, Bankco can serve as the counterparty for an investor on the other side of each position who, on a net basis, takes these positions to hedge risk associated with an otherwise open position with respect to a risky asset. Bankco, however, is able to transfer the market risk associated with its net position to government through the income tax system. The required 
scaling of the positions to realise this result can be generalised as a function of the formula: ${ }^{29}$

long - short OR short - long = net exposure

where

short $=$ long $\mathrm{x}(1-t$ long $) /(1-$ tshort $)$ OR

long $=$ short $\mathrm{x}(1-$ tshort $) /(1-$ tlong $)$

$t=$ tax rate for long or for short

\section{Policy Implications of Scaling}

To summarise the descriptive propositions illustrated by examples 4 to 9 , scaling of risky positions permits risk sharing between taxpayers and government to be magnified. Under symmetric tax rates, scaling can ensure that the risk associated with pre-tax cash flows is maintained while transferring an additional risky revenue stream to government in the process. Under asymmetric tax rates, government also assumes a risky revenue stream which is similarly magnified by scaling to provide either:

- $\quad$ offsetting after-tax cash flows;

- $\quad$ offsetting after-tax cash flows equal to the desired pre-tax cash flows in the absence of scaling; or

- $\quad$ offsetting after-tax cash flows with imperfectly offsetting pre-tax cash flows equal to an unhedged position.

As the basis of an apparent policy problem, a focus on a distinction between risk sharing and risk transfer appears to assume an environment of symmetric tax rates and the absence of scaling as a benchmark in much the same manner as that emphasised by Domar-Musgrave. Scaling alters government's risky revenue stream by magnifying positions in risky assets and, in this sense, there is a risk transfer, albeit there is still risk sharing determined as a function of tax rates. With both symmetric and asymmetric tax rates, scaling of positions does not alter the gain/loss ratio that determines the sharing proportion, but the magnitude of the positions is altered, with government effectively serving a risk-bearing function through the income tax system. Moreover, the additional risky revenue stream created by scaling the positions of one taxpayer is not necessarily offset by an opposite risky revenue stream of a market counterparty, who may hedge the scaled position and/or may be subject to different effective tax rates, including taxation in another jurisdiction; nor is it clear that the market risk transferred to government through scaling is uncorrelated, which would reduce its exposure. In the absence of a willingness or an ability to assess and

29 TD 2010/12, supra note 1 , at para. 8 . 
transfer the additional risky revenue stream back into the market, government serves as an involuntary counterparty with an open market position. ${ }^{30}$

This ability to scale risky positions has focused the associated policy debate in the academic literature on the extent to which returns to risk are actually taxed under a personal income tax. To the extent that scaling of such positions is unconstrained, taxpayers can eliminate the taxation of returns to risk. The non-taxation of risk means that an income tax is comparable to a consumption tax in this respect, with the principal difference being the treatment of time-value returns which are taxed under an income tax but not a consumption tax. ${ }^{31}$ Consumption tax proponents argue that such returns are historically modest and that a consumption tax can be preferred over an income tax for administrative and compliance cost reasons. Income tax proponents argue that the minimal differences between the two choices of tax base mean that the efficiency gains attributable to a consumption tax have been overstated, and an income tax can be preferred given difficult transitional issues in moving to a consumption tax.

More realistically, however, it is recognised in the academic literature that two common features of personal income tax systems constrain the ability to scale the magnitude of the bet element associated with risky assets. One such feature is limitations on the recognition of losses. When such limitations are binding, they eliminate the effective loss refundability that is required for scaling to be effective. The other feature is progressive personal tax rates. In this rate environment, scaling a risky position means that gains may be subject to a higher tax rate which alters the required scaling ratio ex post. ${ }^{32}$ Given these tax constraints on scaling, governments are able to tax returns to

30 See Alan J. Auerbach, "Notes on Taxation and Risk Taking" (2009) 24 Australian Tax Forum 31 , at 34-38 (reviewing the assumptions on which Kaplow's model is based, including the assumption that government can and will sell undiversifiable risk back into the market); Alan J. Auerbach, "How Much Equity Does the Government Hold?" (2004) 94 American Economic Review 155 (estimating the sensitivity of the US government's present-value revenue stream to movements in the stock market as equivalent to an implicit equity position of 1.8 times the entire stock market); and Geoffrey Brennan and Michael Brooks, "Revenue Risk and Revenue Timing: A View from Rational Choice Politics" (2009) 24 Australian Tax Forum 89 (arguing that the political discount rate for the risky revenue stream may not equal the market discount rate). See also James Hollis, "Section 46 of and Schedule 16 to the Finance Act 2010: Risk Transfer Schemes" [2010] no. 5 British Tax Review 444, at 446 ("HMRC are apparently concerned not just that the pricing of the risk the Exchequer was being asked to assume is inappropriate, but that it is not in a position for it to be running such risks at all, since, unlike a commercial hedge provider, it is not in a position to assess the risk.").

31 Neil Brooks, "An Overview of the Role of the VAT, Fundamental Tax Reform, and a Defence of the Income Tax," in David White and Richard Krever eds., GST in Retrospect and Prospect (Auckland: Thomson, Brookers Publishing, 2007) 597, at 646-48.

32 See Daniel Shaviro, The 2008-09 Financial Crisis: Implications for Income Tax Reform (NYU Law and Economics Research Paper No. 09-35, 15 August 2009), at 13 (suggesting that a progressive tax rate structure is the principal source of asymmetric taxation for individual entrepreneurs, while loss limitations are the principal source for large publicly-traded corporations). The extent that loss limitations are binding, and thereby result in asymmetric taxation of gains and losses, 
risk. ${ }^{33}$ In fact, loss limitations and progressive personal income tax rates have much the same effect as transaction costs and other non-tax factors, such as constraints on the ability to borrow at rates below expected returns on risky assets, which also constrain scaling. ${ }^{34}$ Moreover, loss limitations and progressive personal income tax rates have independent normative significance and have generally been seen by tax policymakers to trump possible efficiency losses associated with any behavioural response to asymmetric tax rates for gains and losses. The singular exception in this respect is a hedge tax accounting regime.

Given the tax and non-tax constraints in the context of the personal income tax, it is perhaps not surprising that there is no systematic empirical evidence of tax-driven scaling of speculative positions in this particular context. ${ }^{35}$ It is, however, somewhat surprising that, in the context of the corporate income tax, the academic literature, both theoretical and empirical, has universally ignored the possibility of scaling of risky asset positions and any associated policy significance. ${ }^{36}$ The inattention is curious since one of the principal tax constraints on scaling - progressive tax rates - is either a non-existent feature of corporate income tax systems or, at least, not as pervasive. As a result, scaling is largely unconstrained by tax factors provided that limitations on the recognition of losses are not binding. With fixed gain/loss tax rates that are symmetric, the focus of scaling is the elimination of the taxation of risky returns associated with speculative positions. With fixed gain/loss tax rates that

may differ under the personal income tax and the corporate income tax. See, for example, Alan J. Auerbach, Leonard E. Burman, and Jonathan M. Siegel, "Capital Gains Taxation and Tax Avoidance: New Evidence from Panel Data," in Joel Slemrod ed., Does Atlas Shrug? The Economic Consequences of Taxing the Rich 355, at 377-78 (New York: Russell Sage Foundation, Harvard University Press, 2000) (finding that most individuals in the United States were able to deduct capital losses within one or two years of realisation given the ability to deduct up to $\$ 3,000$ of such losses annually against ordinary income).

33 See Reuven Avi-Yonah, "Risk, Rents, and Regressivity: Why the United States Needs Both an Income Tax and a VAT" (2004) 105 Tax Notes 1651.

34 See Brooks, supra note 31, at 609-17. See also David Elkins and Christopher H. Hanna, "Taxation of Supernormal Returns" (2008) 62 The Tax Lawyer 93 (scaling is unavailable with assets yielding supernormal returns to human capital and should be taxed under a consumption tax); Deborah H. Schenk, "Saving the Income Tax with a Wealth Tax" (2000) 53 Tax Law Review 423 (arguing that the imputation of interest at the riskless rate on all capital assets is normatively desirable as a tax base, since the return to risk is taxed only accidentally under an income tax when non-tax factors constrain the ability to alter portfolios in response to the tax); and Lawrence Zelenak, "The Sometimes-Taxation of the Returns to Risk-Bearing Under a Progressive Income Tax" (2006) 59 SMU Law Review 879 (emphasising the erratic taxation of risk under progressive tax rates). But see Brennan, supra note 23 (demonstrating that asymmetric treatment of risky returns produces tax burdens that are both systematic and quantifiable).

35 See Weisbach, supra note 22, at 45-47 (surveying the empirical literature on taxation and portfolio choice and characterising it as inconclusive).

36 See Feder, supra note 7, at 1613 (noting that conventional wisdom holds that the limited application of hedge tax accounting regimes to a single entity in which both an underlying risk and a hedge of it are located can lead to tax fragmentation where the hedging function is centralised in a single entity and risk is incurred in other entities of the same corporate group). 
are asymmetric, the focus of scaling shifts from the elimination of the taxation of risky returns associated with speculative positions to the elimination of risk through hedging.

At one extreme, unconstrained scaling in this tax environment means that government can be made the involuntary hedge counterparty for all market risk which is effectively transferred to it by the corporate sector through the income tax system. At the other extreme, if scaling is entirely constrained by non-tax factors and/or binding loss limitations, speculative positions, as well as hedge transactions that provide offsetting pre-tax cash flows, generate a revenue stream which is positive where loss limitations are binding (that is, an effective zero loss tax rate) and is risky where tax rates are either symmetric and fixed or asymmetric and fixed with effective loss refundability because of non-binding loss limitations. The empirical reality is probably somewhere in between these two extremes. That is, there is a range of corporate taxpayers who do not face binding loss limitations and can transfer risk to government through the income tax system by scaling speculative positions or by scaling offsetting positions taxed at asymmetric rates; there is also a range of corporate taxpayers who cannot effect the same risk transfer through scaling either because they are subject to binding loss limitation $s^{37}$ or are otherwise constrained by non-tax factors.

In the absence of a market failure that would suggest government should play a role in assuming the relevant risk, ${ }^{38}$ there is no normative basis to support such risk transfers through scaling. In short, it is not obvious that government needs to serve a risk bearing role where diversification is otherwise available and derivative markets are complete in the sense that risk associated with an asset or liability can be hedged. Furthermore, the incidence of risk transfer through scaling is the random outcome of the presence of binding non-tax constraints on such behaviour ${ }^{39}$ as well as the tax

37 See, for example, Alan J. Auerbach, "Why Have Corporate Tax Revenues Declined? Another Look" (2007) 53 CESIFO Economic Studies 153 (finding that non-deductible current losses net of net operating losses in the corporate sector increased from 11 percent of income in 1996-97 to 44 percent in 2001-03); Rosanne Altshuler and Alan J. Auerbach, "The Significance of Tax Law Asymmetries: An Empirical Investigation” (1990) 105 Quarterly Journal of Economics 61 (finding for the period 1971-82 that one-half of firms in the non-financial sector, weighted by book assets, were required to carry forward tax benefits); and Michael Cooper and Matthew Knittel, "Partial Loss Refundability: How Are Corporate Tax Losses Used?” (2006) 59 National Tax Journal 651 (finding for a dataset of firms for the period 1993-2003 that: (i) 50-60 percent of tax losses are used over a ten-year carryover period; and (ii) 25-30 percent of tax losses expire unused).

38 See David A. Moss, When All Else Fails: Government as the Ultimate Risk Manager (Cambridge, Mass.: Harvard University Press, 2002). To the extent that risk transferred through scaling is uncorrelated, government can be seen to provide a form of tolerable subsidised insurance to selfselecting taxpayers. This role may be served more effectively by larger governments with larger tax bases and offsetting positions. But see the sources cited supra note 30.

39 See Feder, supra note 7, at 1615 (describing some non-tax constraints on scaling, which include: (i) the focus of some publicly-traded entities on pre-tax cash flows rather than after-tax cash flows for financial statement purposes; and (ii) regulatory requirements faced by banks, insurance companies and securities dealers). 
constraint imposed by binding loss limitations on some corporate taxpayers. ${ }^{40}$ In this respect, one of us has argued elsewhere for the adoption of a binding loss limitation applicable to the speculative positions of traders in deep and liquid markets for financial instruments that permit diversification of risk at low transaction costs. ${ }^{41}$ As with scaling of open positions, risk-transfer transactions in the context of imperfectly offsetting pre-tax positions that are scaled in the presence of asymmetric tax rates would be acceptable from a public policy perspective only if its apparently random incidence disguised a proxy that suitably identified those corporate taxpayers who, in fact, face undiversifiable risk that government could justifiably bear as a means to correct an associated market failure. Yet this proposition seems unlikely, in which case tax policymakers should also consider some form of loss limitation that eliminates the transfer of risk through the income tax system in this different context. But tax policymakers are left to respond, if at all, in a state of empirical ignorance with, at best, fragmentary transactional evidence of scaling as a hedge strategy.

Because a risk-transfer transaction in the context of hedged positions is commonly structured to avoid application of a hedge tax accounting regime providing symmetric timing and character recognition, the presence of such a regime may seem relevant to the case for adoption of a loss limitation. ${ }^{42}$ In effect, it might be thought that the case for a loss limitation is more compelling where tax policymakers have provided symmetric gain/loss tax rates to remove any tax barriers to hedge transactions, but a range of corporate taxpayers construct their hedge transactions to avoid this treatment and instead transfer risk to government through the income tax system by scaling what would otherwise be offsetting pre-tax cash flows. As an initial proposition, however, the presence or absence of a hedge tax accounting regime providing symmetric tax treatment of offsetting pre-tax cash flows should not be seen

40 See, in this respect, Technical Note, supra note 10, at 5 (“... since these transactions would not be commercially viable for the business if the risks could not be passed on to the Exchequer, they allow groups to enter into arrangements that are intrinsically non-commercial, distort activity and provide groups that are prepared to undertake these transactions with an unfair advantage."). The need for a tax base large enough to support the tax volatility associated with risk-transfer transactions may limit such transactions, for all practical purposes, to a small number of large publicly-traded corporations. But see, Aggressive Tax Planning based on AfterTax Hedging, supra note 4, at 7 and 41 (noting that risk-transfer transactions "... originated in the banking sector, but there is evidence that they are also used in other industries and, in some instances, also by medium-sized enterprises, thus generating an even bigger threat to revenue.").

41 Tim Edgar, "Financial Instability, Tax Policy and the Tax Expenditure Concept" (2010) vol. 63 SMU Law Review 969, at 1023-25 But see, in this respect, Technical Note, supra note 10, at 1 (noting that the loss limitation proposals applicable to risk-transfer schemes do not seek to disturb in any way the treatment of trading gains and losses on unhedged speculative positions taken by financial traders and others in financial instruments that are not part of such arrangements).

42 See, for example, Technical Note, supra note 10, at 1 (noting the UK government's concerns with those overhedging and underhedging arrangements which sidestep or exploit the hedge tax accounting regime to obtain levels of financing costs commensurate with exposure to certain economic risks while effectively passing those risks to the Exchequer). 
as somehow determinative of the need for a loss limitation applicable to risk-transfer transactions.

Where a hedge tax accounting regime does not exist, tax policymakers have presumably decided that any effect of asymmetric treatment of offsetting positions on the level of hedging undertaken by taxpayers is not significant enough to warrant the associated administrative and compliance issues. It is not clear that this decision implies an acceptance of the risk transfer effect associated with scaling of pre-tax positions to provide offsetting after-tax cash flows. Where a hedge tax accounting regime does exist, administrative and compliance considerations may dictate incomplete application. In particular, such regimes tend to be limited in their application to domestic taxpayers and transactions. In addition they tend to focus on symmetric timing and character treatment of offsetting positions and do not extend to the asymmetric treatment attributable to different statutory tax rates of corporate group members subject to different tax jurisdictions. Taxpayers may take advantage of incompleteness to structure hedge strategies to avoid the application of the symmetric treatment associated with a hedge tax accounting regime and to attract the application of asymmetric gain/loss tax rates and the risk transfer through the income tax system that is the result of scaling otherwise offsetting pre-tax cash flows.

In either legislative environment (that is, with or without a hedge tax accounting regime), there may be a range of corporate taxpayers who will scale offsetting positions to provide an effective after-tax hedge with a consequent transfer of risk through the income tax system. Arguably, the motivation for doing so is entirely irrelevant. Although the range of corporate taxpayers who scale offsetting positions may be greater where a hedge tax accounting regime has not been adopted, this difference is one of degree and not one of kind in the sense that the problematic policy attributes described above are somehow different. As an initial proposition, therefore, a loss limitation may be adopted irrespective of the presence or absence of a hedge tax accounting regime. We describe in the next part below what that response might be and what other factors may suggest that the response be narrowed in its targeting, leaving a range of risk-transfer transactions unaffected.

\section{Designing a Loss Limitation}

The lack of any normatively compelling rationale for the transfer of risk to government through the income tax system by some corporate taxpayers, but not others, means that tax policymakers should respond by eliminating the benefit of scaling of offsetting risky positions subject to asymmetric gain/loss tax rates. Ideally, this result would be realised through a loss limitation applicable to such transactions generally: that is, a loss limitation rule that extends to any hedging strategy providing imperfectly offsetting pre-tax cash flows but perfectly or near perfectly offsetting after-tax cash flows.

This kind of targeted legislative response is required where, as described above in part three, it is decided that the consequential attributes of risk-transfer transactions 
that do not provide a tax benefit are sufficiently problematic. In this respect, it is notable that judicial responses to tax-driven straddle transactions have been, at best, incomplete. In contrast with a broad range of risk-transfer transactions that do not provide a tax benefit, these transactions involve perfectly or near-perfectly offsetting pre-tax cash flows, with the taxpayer manipulating realisation-based recognition to accelerate recognition of loss while deferring offsetting gain. ${ }^{43}$ In the absence of a targeted loss limitation like the US straddle rules, ${ }^{44}$ tax administrators are left to challenge these tax-driven transactions under general anti-tax-avoidance rules ${ }^{45}$ and/ or doctrines. ${ }^{46}$ Creative characterisations of the transactions as a single property have met with only limited success in litigation. ${ }^{47}$

43 The tax effectiveness of a straddle depends on a strict adherence to the realisation requirement as the appropriate timing rule for the recognition of unexpected gain or loss, as well as an acceptance of the legal form of the offsetting legs as separate financial instruments. This kind of reliance on legal form is apparent in the decision of the Supreme Court of Canada in The Queen v. Friedberg, 93 DTC 5507; [1993] 2 CTC 306 which expressly confirmed that the daily crediting or debiting of the margin accounts of taxpayers engaged in futures trading is a security arrangement only and does not constitute a realisation event. Absent a specific legislative provision requiring the netting of realised losses against unrealised gains, the court concluded that long and short positions in futures contracts should be regarded as separate financial instruments that are accounted for separately on a realisation basis.

44 IRC, section 1092. US policymakers reacted early and swiftly with this specific legislation intended to address the marketing of commodity straddles by the tax shelter industry in the late 1970s and early 1980s. Staff of the Joint Committee on Taxation, 97th Congress, 1st Session, General Explanation of the Economic Recovery Tax Act of 1981, (Washington: Joint Committee Print, 1981), at 282-83. The legislation is nothing more than a loss limitation rule based on the integration of offsetting positions that comprise a straddle. The basic limitation applies to "offsetting positions with respect to personal property."

45 The ATO has stated that it will normally deny the recognition of losses on straddle transactions on the basis that it is necessary to have regard to the overall result of the entire set of transactions implemented for avoidance purposes. See Income Tax Rulings IT 2228; Roger Paul, "Financial Risk Management and the Taxation of Financial Products," in Taxation of Corporate Debt Finance, Rick Krever, Yuri Grbich and Patrick Gallagher eds., (Melbourne: Longman Professional Publishing, 1991), 209, at 237-38; and David C. Temby, "Swaps, Options, Forwards and Futures," in Australian International Taxation: Recent Developments and Future Directions, Richard Krever and Yuri Grbich, eds, (Sydney: The Law Book Company, 1994), 119, at 151-52.

46 Before the enactment of specific legislation, some US courts held that recognition of realised losses on the losing leg of a straddle were denied either because the transactions were shams in the sense that they were never implemented or, if valid transactions, the taxpayers could not show that they were entered into with a profit motive. See Frank V. Battle, Jr., "Corporate Tax Shelters, Financial Engineering and the Colgate Case" (1997) 75 Taxes 692, at 694-95; and Bradford L. Ferguson, “The Rationales for the Rules: How to Think About Derivatives in the Tax World” (1994) 72 Taxes 995, at 1023, footnote 140.

47 See, for example, Schultz v. The Queen, 95 DTC 5657; [1996] 2 CTC 127 (FCA) (straddle transactions of husband and wife characterised as a partnership and, therefore, requiring proportionate recognition of gain and loss by partners); and Hayes et al. v. The Queen, 2003 DTC 1205 (TCC) (characterising offsetting long and short positions as a single property with gain 
We describe in the next part of the article how general anti-tax-avoidance rules and/or doctrines can be similarly used to address the limited range of risk-transfer transactions that are entered into to provide a tax benefit. For the broader range of transactions that cannot be so characterised, the transfer of market risk through the income tax system can be completely addressed only through a legislative loss limitation. ${ }^{48}$ Experience with tax-driven straddle transactions would suggest that judicially-creative characterisations of the transactions under general income tax rules and/or principles cannot possibly provide a complete and consistent response.

As emphasised already, the increased magnitude of the risky revenue stream that is the result of scaling does not dictate, in principle at least, a limited focus on the kinds of structured risk-transfer transactions in examples 1 to 3 that are the target of limited responses by UK Inland Revenue and the ATO. The broader dimension of the policy problem suggests a much broader policy response in the form of a loss limitation applicable to risk-transfer transactions generally. Costliness associated with the identification exercise may be seen, however, to require a more limited response to a subset of risk-transfer transactions, particularly where tax policymakers perceive that the problematic policy consequences of the broader set of these transactions are less severe than the behavioural response that might result from the incompleteness of a hedge tax accounting regime or the lack of such a regime. In effect, tax policymakers may be willing to tolerate a range of risk-transfer transactions on the basis of an empirical assumption that non-tax factors, the necessary tax conditions and, in some instances, the presence of a hedge tax accounting regime serve to suitably constrain implementation of such transactions to an extent that they present a tolerable risky revenue exposure. The presence of a hedge tax accounting regime can be seen, therefore, to support a more narrowly-targeted loss limitation.

\section{A Form of Loss Denial}

Because the tax effectiveness of scaling depends on the ability to offset losses against income subject to the same tax rate, a non-recognition rule for the scaled portion of pre-tax losses would eliminate that effectiveness. In other words, this kind of nonrecognition rule would negate the risk transfer otherwise attributable to scaling by disturbing the after-tax equivalence of imperfectly offsetting pre-tax cash flows subject to asymmetric tax rates. The scaled portion of any pre-tax loss is a function of the formula:

and loss recognised only on close out of both positions). But see Rezek et al. v. The Queen, 2005 DTC 537 (FCA) (rejecting single property characterisation and treating straddle transactions of husband and wife as a partnership).

48 See UK Chartered Institute of Taxation, "Overhedging and Underhedging HMRC Technical Note August 2009 - Response by the Chartered Institute of Taxation," 29 September 2009, at para 10.1 (characterising as novel the focus of the UK loss limitation on risk transfer rather than tax avoidance). 
$\mathrm{SP}=\mathrm{A} \times t$

where

$\mathrm{SP}=$ the scaled portion of the realized loss

$A=$ the pre-tax loss

$t=$ the tax rate applicable to scaled position giving rise to the pre-tax loss

This kind of loss non-recognition rule could also be one-sided in the sense that any gain associated with a targeted transaction would be fully subject to tax at the relevant rate. The one-sided nature of this suggested rule would serve as a penalty in an attempt to deter scaled hedge transactions and the risk transfer that would otherwise occur. As applied to the foreign-currency hedges in examples 1 and 2, the effect of this one-sided loss limitation rule on after-tax cash flows of a taxpayer and government revenue is summarised in table 10.1 below.

Table 10.1

\begin{tabular}{|c|c|c|c|c|c|c|c|c|}
\hline GBP/JPY & $-30 \%$ & $-20 \%$ & $-10 \%$ & $-5 \%$ & $5 \%$ & $10 \%$ & $20 \%$ & $30 \%$ \\
\hline $\begin{array}{l}\text { Realised FX } \\
\text { gain/loss }\end{array}$ & (41.70) & $(27.80)$ & (13.90) & (6.95) & 6.95 & 13.90 & 27.80 & 41.70 \\
\hline $\begin{array}{l}\text { Non-deductible } \\
\text { loss }\end{array}$ & (11.70) & $(7.80)$ & (3.90) & (1.95) & 0 & 0 & 0 & 0 \\
\hline Deductible loss & (30) & (20) & (10) & (5) & 0 & 0 & 0 & 0 \\
\hline Tax payable & $(8.40)$ & $(5.60)$ & $(2.80)$ & $(1.40)$ & 1.95 & 3.90 & 7.80 & 11.70 \\
\hline Net after-tax & (33.30) & $(22.20)$ & $(11.10)$ & (5.55) & 5 & 10 & 20 & 30 \\
\hline $\begin{array}{l}\text { Unrealised FX } \\
\text { gain/loss }\end{array}$ & 30 & 20 & 10 & 5 & (5) & (10) & (20) & (30) \\
\hline Tax payable & 0 & 0 & 0 & 0 & 0 & 0 & 0 & 0 \\
\hline $\begin{array}{l}\text { Net after-tax: } \\
\text { Group XY }\end{array}$ & (3.30) & $(2.20)$ & (1.10) & $(0.55)$ & 0 & 0 & 0 & 0 \\
\hline Net revenue & $(8.40)$ & (5.60) & $(2.80)$ & $(1.40)$ & 1.95 & 3.90 & 7.80 & 11.70 \\
\hline
\end{tabular}

No loss limitation (Tables 1.1 and 2.1)

\begin{tabular}{l|l|l|l|l|l|l|l|l}
\hline Net revenue & $(11.70)$ & $(7.80)$ & $(3.90)$ & $(1.95)$ & 1.95 & 3.90 & 7.80 & 11.70 \\
\hline $\begin{array}{l}\text { Net after-tax: } \\
\text { Group XY }\end{array}$ & 0 & 0 & 0 & 0 & 0 & 0 & 0 & 0 \\
\hline
\end{tabular}


Because only one side of the offsetting positions in examples 1 and 2 are scaled, the suggested loss limitation rule would only apply to this position in the event that the GBP depreciated in value against the JPY and a loss was realised. The first four columns in table 10.1 indicate the scaled portion of the loss that would be denied recognition and would thereby reduce the associated tax saving for different changes in value as between the GBP and the JPY. This reduced loss recognition, limited to the non-scaled portion of the relevant position, would mean that the consolidated foreign exchange gain and loss of the offsetting positions would no longer match, resulting in a net after-tax loss for the corporate group shown again in the first four columns of table 10.1 for different changes in value of the GBP against the JPY. Government's loss exposure would also be reduced as compared to the case of full loss recognition, the results of which are summarised in tables 1.1 and 2.1 and are reproduced at the bottom of table 10.1 for comparison purposes. As the last four columns show, the full amount of any scaled gain realised if the GBP appreciates against the JPY would remain taxable and government's net revenue would remain the same as shown in tables 1.1 and 2.1. There would be a complete matching of the after-tax results in this case because the non-scaled position is effectively non-taxable and any offsetting loss would not be attributable to scaling. The hedge transaction would presumably not be entered into, however, provided the relevant long and short positions were priced on market, and there would thus be no way to ensure that unexpected gain and loss attributable to changes in relative value as between the GBP and the JPY would arise systematically on the same offsetting positions.

The asymmetric swap in example 3 involves scaling of both offsetting positions such that our suggested loss limitation would apply equally to both positions. As with the foreign-currency hedges in examples 1 and 2, the loss limitation would alter the after-tax offsetting cash flows such that government's loss exposure would be reduced as compared to full recognition of the non-scaled and scaled portion of the losses. Application of the loss limitation to the scaled portion of both sides of the asymmetric swap means that government revenue increases in the event that the position subject to the higher tax rate provides the gain and the position subject to the lower tax rate provides the loss. This effect can be seen in the last four columns of table 10.2.

Table 10.2

\begin{tabular}{l|c|c|c|c|c|c|c|c}
$\begin{array}{l}\text { Rise/fall } \\
\text { value of } \\
\text { equity index }\end{array}$ & $-\mathbf{- 1 0 0 \%}$ & $\mathbf{- 7 5 \%}$ & $\mathbf{- 5 0 \%}$ & $\mathbf{- 2 5 \%}$ & $\mathbf{2 5 \%}$ & $\mathbf{5 0 \%}$ & $\mathbf{7 5 \%}$ & $\mathbf{1 0 0 \%}$ \\
$\begin{array}{l}\text { Short swap: } \\
\text { OBU }\end{array}$ & 525 & 393.75 & 262.50 & 131.25 & $(131.25)$ & $(262.50)$ & $(393.75)$ & $(525)$ \\
\hline $\begin{array}{l}\text { Non-deductible } \\
\text { loss }\end{array}$ & 0 & 0 & 0 & 0 & $(13.12)$ & $(26.25)$ & $(39.38)$ & $(52.50)$ \\
\hline Deductible loss & 0 & 0 & 0 & 0 & $(118.13)$ & $(236.25)$ & $(354.37)$ & $(472.50)$ \\
\hline Tax payable & 52.50 & 39.38 & 26.25 & 13.13 & $(11.81)$ & $(23.63)$ & $(35.44)$ & $(47.25)$ \\
\hline
\end{tabular}




\begin{tabular}{|c|c|c|c|c|c|c|c|c|}
\hline $\begin{array}{l}\text { Rise/fall } \\
\text { value of } \\
\text { equity index }\end{array}$ & $-100 \%$ & $-75 \%$ & $-50 \%$ & $-25 \%$ & $25 \%$ & $50 \%$ & $75 \%$ & $100 \%$ \\
\hline After-tax & 472.50 & 354.37 & 236.25 & 118.12 & (119.44) & $(238.87)$ & (358.31) & $(477.75)$ \\
\hline $\begin{array}{l}\text { Long swap: } \\
\text { DBU }\end{array}$ & (675) & (506.25) & (337.50) & (168.75) & 168.75 & 337.50 & 506.25 & 675 \\
\hline $\begin{array}{l}\text { Non-deductible } \\
\text { loss }\end{array}$ & (202.50) & (152) & (101.25) & $(50.63)$ & 0 & 0 & 0 & 0 \\
\hline Deductible loss & $(472.50)$ & (354.25) & (236.25) & $(118.12)$ & 0 & 0 & 0 & 0 \\
\hline Tax payable & $(141.75)$ & (106.25) & (70.88) & (35.44) & 50.63 & 101.25 & 151.88 & 202.50 \\
\hline After-tax & (533.25) & $(400)$ & (266.62) & (133.31) & 118.12 & 236.25 & 354.37 & 472.50 \\
\hline $\begin{array}{l}\text { Net position: } \\
\text { OBU and DBU }\end{array}$ & $(60.75)$ & (45.63) & $(30.37)$ & (15.19) & (1.32) & (2.62) & (3.94) & (5.25) \\
\hline $\begin{array}{l}\text { Tax payable: } \\
\text { short swap }\end{array}$ & 52.50 & 39.38 & 26.25 & 13.13 & (11.81) & (23.63) & (35.44) & (47.25) \\
\hline $\begin{array}{l}\text { Tax payable: } \\
\text { long swap }\end{array}$ & (141.75) & (106.25) & $(70.88)$ & $(35.44)$ & 50.63 & 101.25 & 151.88 & 202.50 \\
\hline Net tax payable & (89.25) & (66.87) & $(44.63)$ & (22.31) & 38.82 & 78.12 & 116.44 & 155 \\
\hline
\end{tabular}

No loss limitation (Table 3.1)

\begin{tabular}{l|c|c|c|c|c|c|c|c}
\hline $\begin{array}{l}\text { Net position: } \\
\text { OBU and DBU }\end{array}$ & 0 & 0 & 0 & 0 & 0 & 0 & 0 & 0 \\
\hline $\begin{array}{l}\text { Tax payable: } \\
\text { short swap }\end{array}$ & 52.50 & 39.38 & 26.25 & 13.13 & $(13.13)$ & $(26.25)$ & $(39.38)$ & $(52.50)$ \\
\hline $\begin{array}{l}\text { Tax payable: } \\
\text { long swap }\end{array}$ & $(202.50)$ & $(151.88)$ & $(101.25)$ & $(50.63)$ & 50.63 & 101.25 & 151.88 & 202.50 \\
\hline Net tax payable & $(150)$ & $(112.50)$ & $(75)$ & $(37.50)$ & 37.50 & 75 & 112.50 & 150 \\
\hline
\end{tabular}

The UK loss limitation applicable to "risk-transfer schemes" also disturbs the after-tax equivalence of cash flows from offsetting positions that are scaled, which negates the transfer of risk to government through the income tax system; it realises this result, however, in a manner different from our suggested loss limitation and similar to the US straddle legislation, which permits the recognition of realised losses only to the 
extent that they exceed unrealised gains on an offsetting position. ${ }^{49}$ The amount of the limited losses under the UK legislation is a function of the following formula: ${ }^{50}$

total scheme loss $\mathrm{x}$ ([total scheme loss - total scheme profit] - pre-tax economic loss from the scheme/ total realised scheme loss)

"Total scheme loss" and "scheme profit" are amounts realised in the relevant taxation year and are defined as those profits and losses that arise from movements in a rate or index that is central to the scheme and which arise from a loan relationship or derivative contract that, apart from the scheme, would have been brought to account within the hedge tax accounting rules. "Pre-tax economic loss" is the excess of realised and unrealised losses over realised and unrealised gain. ${ }^{52}$ Any excess of realised scheme losses over realised scheme profits may be carried over and deducted against scheme profits in a subsequent year. ${ }^{53}$

The different form of loss limitation under the UK legislation appears to follow from a focus on an assumed structuring to otherwise avoid hedge tax accounting treatment. By matching the non-scaled portion of a loss with scheme profit, that portion of the loss is effectively deducted at the tax rate applicable to gain realised on the offsetting position rather than the tax rate at which the loss position was scaled. Realisation of offsetting after-tax cash flows and the associated risk transfer requires recognition of the full amount of pre-tax gain and loss independently at the asymmetric tax rates applicable to the positions. The UK loss limitation rule thus disturbs this required recognition by limiting recognition of the non-scaled portion of realised loss. The scaled portion of any realised scheme loss reflected in a pre-tax economic loss is essentially considered to be unhedged and may be recognised subject to the application of any other loss limitation rules. Our suggested loss limitation realises a comparable result by limiting recognition of the scaled portion of realised loss. As with our suggested loss limitation, the UK rule is also one-sided in the sense that any realised gain attributable to the scaled portion of a position must be recognised.

The effect of the application of the UK loss limitation to the foreign-currency hedge transactions in examples 1 and 2 is summarised in table 11.1. It can be seen that, as compared to the effect of our suggested loss limitation summarised in table 10.1, the UK rule provides more limited revenue exposure and a deeper net loss position for the taxpayer in examples 1 and 2, because the whole of the non-scaled portion of the scheme loss is denied recognition for the year in the absence of any realised scheme profit on the offsetting position. The non-deductible portion of the loss is

49 IRC, section 1092. Recognition of realised losses is permitted only to the extent that they exceed unrealised gain on an offsetting position. Moreover, realised gain on a winning position must be recognised in full and is not limited to the excess of such gain over unrecognised loss on an offsetting losing position. The basic loss limitation is supplemented with a provision that requires the capitalisation of interest and carrying charges related to a straddle. IRC, $\$ 263(\mathrm{~g})$.

50 Corporation Tax Act 2010, section 937F(1).

51 Corporation Tax Act 2010, section 937E.

52 Corporation Tax Act 2010, section 937L.

53 Corporation Tax Act 2010, sections 937G and 937H. 
nonetheless available for carryover against any scheme profits realised in subsequent taxation years.

Table 11.1

\begin{tabular}{l|c|c|c|c|c|c|c|c}
\hline GBP/JPY & $\mathbf{- 3 0} \%$ & $\mathbf{- 2 0} \%$ & $\mathbf{- 1 0} \%$ & $\mathbf{- 5} \%$ & $\mathbf{5 \%}$ & $\mathbf{1 0} \%$ & $\mathbf{2 0} \%$ & $\mathbf{3 0} \%$ \\
\hline $\begin{array}{l}\text { Total scheme } \\
\text { loss }\end{array}$ & $(\mathbf{4 1 . 7 0 )}$ & $(27.80)$ & $(13.90)$ & $(6.95)$ & 0 & 0 & 0 & 0 \\
\hline Scheme profit & 0 & 0 & 0 & 0 & 6.95 & 13.90 & 27.80 & 41.70 \\
\hline $\begin{array}{l}\text { Pre-tax } \\
\text { economic loss }\end{array}$ & $(11.70)$ & $(7.80)$ & $(3.90)$ & $(1.95)$ & 0 & 0 & 0 & 0 \\
\hline $\begin{array}{l}\text { Non-deductible } \\
\text { loss }\end{array}$ & $(30)$ & $(20)$ & $(10)$ & $(5)$ & 0 & 0 & 0 & 0 \\
\hline Deductible loss & $(11.70)$ & $(7.80)$ & $(3.90)$ & $(1.95)$ & 0 & 0 & 0 & 0 \\
\hline Net revenue & $(3.28)$ & $(2.18)$ & $(1.09)$ & $(0.55)$ & 1.95 & 3.90 & 7.80 & 11.70 \\
\hline $\begin{array}{l}\text { Net after-tax: } \\
\text { Group XYY }\end{array}$ & $(8.42)$ & $(5.62)$ & $(2.81)$ & $(1.40)$ & 0 & 0 & 0 & 0 \\
\hline
\end{tabular}

No loss limitation (Tables 1.1 and 2.1)

\begin{tabular}{l|c|c|c|c|c|c|c|c}
\hline $\begin{array}{l}\text { Net revenue } \\
\text { from FX gain/ } \\
\text { loss }\end{array}$ & $(11.70)$ & $(7.80)$ & $(3.90)$ & $(1.95)$ & 1.95 & 3.90 & 7.80 & 11.70 \\
\hline $\begin{array}{l}\text { Net after-tax: } \\
\text { Group XY }\end{array}$ & 0 & 0 & 0 & 0 & 0 & 0 & 0 & 0 \\
\hline
\end{tabular}

The effect of offsetting the non-scaled portion of realised scheme losses against realised scheme profits can be seen with the asymmetric swap in example 3 and is summarised in table 11.2. Where the scheme loss is realised on the higher-taxed position (long swap), the UK loss limitation results in more limited revenue exposure and a deeper net loss position for the taxpayer, because it effectively provides a lower deduction rate for a larger portion of the loss against scheme profits. Our suggested loss limitation would deny recognition of the scaled portion of the loss while allowing the non-scaled portion to be deducted at the higher tax rate applicable to the long swap. Where the gain is realised on the long swap, our suggested loss limitation would result in greater tax payable, because the scaled portion of the realised loss on the short swap would be denied recognition. The UK loss limitation effectively permits the whole of the loss realised on the short swap to be deducted against realised gain on the long swap, with only the excess of the gain subject to tax at the higher tax rate applicable to that position. 
Table 11.2

\begin{tabular}{|c|c|c|c|c|c|c|c|c|}
\hline $\begin{array}{l}\text { Rise/fall } \\
\text { value of } \\
\text { equity index }\end{array}$ & $-100 \%$ & $-75 \%$ & $-50 \%$ & $-25 \%$ & $25 \%$ & $50 \%$ & $75 \%$ & $100 \%$ \\
\hline $\begin{array}{l}\text { Short swap: } \\
\text { OBU }\end{array}$ & 525 & 393.75 & 262.50 & 131.25 & (131.25) & (262.50) & (393.75) & (525) \\
\hline $\begin{array}{l}\text { Long swap: } \\
\text { DBU }\end{array}$ & (675) & (506.25) & (337.50) & (168.75) & 168.75 & 337.50 & 506.25 & 675 \\
\hline $\begin{array}{l}\text { Total scheme } \\
\text { loss }\end{array}$ & (675) & $(506.25)$ & (337.50) & (168.75) & (131.25) & $(262.50)$ & (393.75) & (525) \\
\hline Scheme profit & 525 & 393.75 & 262.50 & 131.25 & 168.75 & 337.50 & 506.25 & 675 \\
\hline $\begin{array}{l}\text { Pre-tax } \\
\text { economic loss }\end{array}$ & (150) & (112.50) & (75) & $(37.50)$ & 0 & 0 & 0 & 0 \\
\hline $\begin{array}{l}\text { Deductible loss } \\
\text { after offset }\end{array}$ & (150) & (112.50) & (75) & $(37.50)$ & 0 & 0 & 0 & 0 \\
\hline Tax payable & (45) & (33.75) & $(22.50)$ & (11.25) & 11.25 & 22.50 & 33.75 & 45 \\
\hline $\begin{array}{l}\text { Net position: } \\
\text { OBU and DBU }\end{array}$ & (105) & (78.25) & $(52.50)$ & (26.25) & 26.25 & 52.50 & 78.75 & 105 \\
\hline
\end{tabular}

No loss limitation (Table 3.1)

\begin{tabular}{l|c|c|c|c|c|c|c|c}
\hline $\begin{array}{l}\text { Net position: } \\
\text { OBU and DBU }\end{array}$ & 0 & 0 & 0 & 0 & 0 & 0 & 0 & 0 \\
\hline $\begin{array}{l}\text { Tax payable: } \\
\text { short swap }\end{array}$ & 52.50 & 39.38 & 26.25 & 13.13 & $(13.13)$ & $(26.25)$ & $(39.38)$ & $(52.50)$ \\
\hline $\begin{array}{l}\text { Tax payable: } \\
\text { long swap }\end{array}$ & $(202.50)$ & $(151.88)$ & $(101.25)$ & $(50.63)$ & 50.63 & 101.25 & 151.88 & 202.50 \\
\hline Net tax payable & $(150)$ & $(112.50)$ & $(75)$ & $(37.50)$ & 37.50 & 75 & 112.50 & 150 \\
\hline
\end{tabular}

\section{B Targeting of Loss Denial}

Our suggested loss limitation probably differs more importantly from the UK rule in its targeting. Consistent with the articulation of the policy problem in the immediately previous part of the article, our suggested limitation would focus generally on transactions that involve scaling of one or more offsetting positions as a means to transfer risk through the income tax system. Similar to the US straddle legislation ${ }^{54}$ and/or hedge transactions eligible for hedge tax accounting treatment,

54 For an overview of the US straddle legislation, see Peter C. Canellos, "Limitations on Loss Recognition," in Reuven S. Avi-Yonah, David B. Newman, and Diane Ring eds., Taxation of Financial Instruments (Deerfield, Ill: Clark, Boardman Callaghan) (loose-leaf), chapter 6, at 10- 
affected transactions would be defined in terms of offsetting positions. The principal difference with the definition of offsetting positions in these different contexts would be the identification of positions with imperfectly offsetting pre-tax cash flows and perfectly or near-perfectly offsetting after-tax cash flows. ${ }^{55}$

The UK loss limitation focuses on a narrower subset of risk-transfer transactions using loans and derivative contracts that result in the acquisition of a financial advantage and not just the transfer of risk through the income tax system. In particular, a "risktransfer scheme" 56 is a scheme that satisfies the following conditions:

- the main purpose of any member of a corporate group entering into the scheme is to obtain a "financial advantage," defined as an increase on returns on investments, a reduction in the costs of borrowing, or a similar economic impact arising from the combination of the effect of the scheme on corporate group members; ${ }^{57}$

- $\quad$ it is reasonable to assume that the financial advantage could not have been obtained without being subject to the "relevant risk," defined as the fluctuation in any index, price or value; ${ }^{58}$

- the result of entering into the scheme is that the group is not subject to the risk; and

- the group would be subject to the risk if the operation of the tax system were ignored.

There are arguably two possible, and not necessarily alternative, rationales for this more limited focus. One possible rationale is a perceived need to limit compliance and administrative costs associated with the identification of offsetting positions. Identification costs can, indeed, be severe in the absence of any required identification

17; and John J. Ensminger, “The Broad but Porous Net of the Straddle Rules: How Long Will the Fish Continue to Swim Through?” (1999) 18 Virginia Tax Review 709.

55 For the most part, the concept of offsetting positions under the US legislation is expressed at a general level of principle and appears to have been intentionally left vague. See Canellos, supra note 54, at 13-14. The legislation provides only that a taxpayer is considered to hold offsetting positions where those positions entail "a substantial diminution of risk of loss" in respect of one another. IRC, section 1092(c)(3)(A) provides that positions are presumed to be offsetting where: (i) they are in the same personal property (whether established in such property or a contract for such property); (ii) they are in the same personal property, even though such property may be in altered form; (iii) they are in debt instruments of a similar maturity; (iv) they are sold or marketed as offsetting positions; or (v) the aggregate margin requirement for the positions is lower than the sum of the margin requirements for each position if held separately. IRC, section 1092(c)(3)(A)(vi) provides that positions are presumed to be offsetting if there are such other factors (or satisfaction of subjective or objective tests) as the Secretary may by regulations prescribe as indicating that such positions are offsetting.

56 Corporation Tax Act 2010, section 937C.

57 Corporation Tax Act 2010, section 937C(6).

58 Corporation Tax Act 2010, section 937C(3). 
of after-tax hedging transactions for financial accounting purposes. ${ }^{59}$ The limited focus of the UK legislation can be seen as an attempt to limit identification costs by focusing on structured or tailored transactions, with the presence of a financial advantage, along with a transfer of risk through the income tax system, serving as a proxy for this set of transactions. Application of the loss limitation rule is further limited to loan and derivative contracts, presumably on the empirical assumption that such contracts can be scaled relatively easily at low transaction costs. ${ }^{60}$ Another possible rationale also rests on another empirical premise that the adoption of a hedge tax accounting regime sufficiently limits the attractiveness of risk-transfer transactions as a hedging strategy. More particularly, it may be assumed that, in the absence of the acquisition of a financial advantage, taxpayers are disinclined to scale positions and will otherwise rely on the timing and character matching provided by a hedge tax accounting regime to ensure symmetry of pre-tax and after-tax results. ${ }^{61}$

Both of these possible rationales for narrowing the focus of a loss limitation rule are problematic. ${ }^{62}$ As we argued earlier, the presence of a hedge tax accounting regime is, in fact, normatively irrelevant to the articulation of the policy problem presented by risk-transfer transactions. The same risk transfer effect holds under the conditions of the availability of asymmetric tax rates and non-binding loss limitations in the absence of a hedge tax accounting regime as in the presence of such a regime that is either incomplete in its application or can be avoided. It is simply unclear empirically that such a regime sufficiently mutes the incentive to transfer risk through the income

59 See in this respect, International Accounting Standards Board (IASB), Guidance on Implementing International Accounting Standard (IAS) 39 Financial Instruments: Recognition and Measurement, at para. F.4.1 ("IAS 39 permits, but does not require, assessment of hedge effectiveness on an aftertax basis. If the hedge is undertaken on an after-tax basis, it is so designated at inception as part of the formal documentation of the hedging relationship and strategy."); and Tony Frost, Jerry Reilly, and Emily Kater, Guide to Taxation of Financial Arrangements (Sydney: Thomson Reuters, 2009), at 363 (noting that the implementation guidance for IAS 39 has no specific Australian equivalent but, "in practice, companies and their auditors are expected to have regard to, and apply, IAS 39 IG."). See also Feder, supra note 7, at 1615, note 10 (noting that the US Financial Accounting Standards Board (FASB) in ACS, para. 815-35-35-3; para. 815-35-35-26, and subpara. 815-20-253 (b)(2)(vi), "has expressly recognized that taxpayers may adjust the notional amount of certain hedges so that those hedges are effective on an after-tax basis"). Where regulatory constraints are non-binding, an ability to offset positions in order to reduce counterparty risk charges to regulatory capital can provide assistance in the identification function.

60 See Schizer, supra note 26 (arguing that, in the presence of scaling, gain and loss recognition rates on derivatives can be any rate provided that it applies symmetrically).

61 See, for example, Aggressive Tax Planning based on After-Tax Hedging, supra note 4, at 37 ("In practice, whether after-tax hedging should be accepted as a natural consequence of the disparate treatment of certain items or should rather be considered as aggressive and challenged will depend on a number of elements, including the facts and circumstances of each case, the commercial reasons underlying the transactions, and the intent of the applicable domestic law.").

62 Chartered Institute of Taxation, supra note 48, at para 3.4 (questioning the targeting of transactions that transfer risk to the Exchequer only if they provide a financial benefit other than a tax benefit). 
tax system where offsetting positions can be constructed such that they are exposed to asymmetric tax rates and realised loss on a scaled position is otherwise fully deductible in the absence of a binding loss limitation. The presence of a financial advantage as defined in the UK legislation represents the more extreme version of such transactions, ${ }^{63}$ but the same ability to transfer risk through the income tax system remains for hedge transactions that do not involve the acquisition of a financial advantage associated with a scaled position. It would seem that only a range of non-tax constraints might constrain the substitution of risk-transfer transactions for conventional hedging transactions with offsetting pre-tax cash flows. The existence of such constraints would likely have random incidence effects that cannot be justified on any policy basis whether or not a hedge tax accounting regime has been adopted by tax policymakers. UK Inland Revenue apparently recognises this fact in the 2009 budget documents where it is acknowledged that the narrowly-targeted loss limitation could be amended in the future to extend to "trading transactions" generally. ${ }^{64}$ This possible extension is now reflected in a regulation-making power that permits extension to trading losses on any instruments, and not just loans and derivative contracts, of banks, insurance companies or broker-dealers. ${ }^{65}$

As far as identification costs are concerned, the broader application of our suggested loss limitation would entail greater costs comparable perhaps to those associated with the US straddle rules. ${ }^{66}$ That said, the more narrowly targeted UK rule is also not without such costs associated with the identification of offsetting positions that constitute a scheme. ${ }^{67}$ Moreover, the identification of a financial advantage imposes its own set of identification costs that would not be a part of our suggested limitation.

63 See, in this respect, Aggressive Tax Planning based on After-Tax Hedging, supra note 4, at 7 and 37 (emphasising that certain risk-transfer transactions are artificial in the sense that there is generally no pre-existing exposure to market price risk, but rather such risk is created as part of the relevant scheme).

64 Technical Note, supra note 10, at 7 (indicating consideration of extension of proposed loss limitation to trading transactions involving instruments other than loan relationships and derivative contracts as part of a risk-transfer scheme).

65 Corporation Tax Act 2010, section 937O.

66 See, for example Canellos, supra note 54, at 14 (“... the IRS faces enormous problems in applying the straddle rules since it has no effective way of identifying offsetting positions without being tipped off by the taxpayer."). Special disclosure rules supported by penalties for non-disclosure have been used in an attempt to address the identification problem. IRC, section 1092(a)(3) (B) and former section 6653(f). However, as Canellos notes, straddle issues have historically been raised on audit where: (i) the taxpayer has elected to treat an offsetting position as a qualifying hedge within the exception from the straddle rules; or (ii) the taxpayer has designated a transaction as a hedge for financial accounting purposes. In both instances, the IRS has notice of the offsetting nature of two or more positions and can challenge their characterisation as qualifying hedges for tax purposes. The alternative is treatment as a straddle.

67 See, for example, Hollis, supra note 30, at 449-50 (describing some modifications of the transactional examples in the Technical Note suggesting that the conditions of application of the UK loss limitation rules may not be satisfied). See also Chartered Institute of Taxation, supra note 48 , at para 6.2 . 
For example, although the presence of the lower borrowing cost associated with the foreign-currency hedge in example 1 and the increased return associated with the foreign-currency hedge in example 2, arguably constitute a financial benefit, it is not clear that the same conclusion can be drawn with the asymmetric swap in example 3 . This transaction would seem to be subject to the UK rule only if it can be concluded that the fee earned for providing the long and short swaps constitutes an economic impact similar to an increase on investment or a reduction in borrowing costs arising from the effect of the scheme on corporate group members and that could not have been obtained without being subject to the relevant market risk. These conditions of application are not self-executing and impose identification costs associated with the necessary interpretative exercise. ${ }^{68}$

Costliness of the identification function is clearly most severe in a cross-border context implicating multiple taxing jurisdictions because of the assumption of offsetting positions by members of the same corporate group subject to different tax rates in different jurisdictions. In fact, this environment commonly provides the necessary conditions for tax-driven scaling of offsetting positions characteristic of risk-transfer transactions. In some instances, transactions are structured to take advantage of these conditions. In other instances, however, there may be factors, such as the facilitation of the risk management function through a centralised centre of a corporate group, that dictate hedging strategies implemented in multiple jurisdictions. In these circumstances, the motivation for tax-effective hedging may not be the ability to transfer risk through the income tax system by scaling of offsetting positions subject to different tax rates. Any resultant risk transfer may be entirely incidental to the need to hedge, on a tax-effective basis, market risk located in different tax jurisdictions.

Whatever its form of loss denial or targeting dimensions, a loss limitation affecting a range of risk-transfer transactions must extend to positions assumed by two or more members of the same corporate group or "affiliated," "related" or "associated" persons; ${ }^{69}$ otherwise, the limitation is too easily avoided. A focus on risk-transfer transactions that are structured to provide a financial benefit may serve as a proxy for the identification of offsetting positions that are assumed by different members of the same group in order to ensure that the positions are subject to asymmetric tax rates. Where the acquisition of a financial benefit is not present, such structuring may be tolerated on the basis that the risk transfer from scaling is diffused among multiple tax jurisdictions. Nonetheless, this is arguably a less than compelling reason to prevent the unilateral adoption and application of a loss limitation rule as a response to the

68 Hollis, supra note 30, at 449-50.

69 See Technical Note, supra note 10, at 3 ("These transactions are structured to create a mix of assets and liabilities whose values are subject to opposing movements, normally across a number of group entities."); and IRC, section 1092(d)(4) (treating taxpayer as holding positions of spouse, other members of a consolidated corporate group and certain partnerships and trusts for the purpose of the straddle rules). 
partial risk transfer that is implicated in one of the jurisdictions. ${ }^{70}$ Our suggested loss limitation would apply therefore to deny recognition of the scaled portion of a realised loss without accounting for the offsetting position in another jurisdiction. Similarly, a UK-style loss limitation applied to risk-transfer transactions generally should deny recognition of the non-scaled portion of a loss realised by a UK taxpayer without any offset for scheme gain realised in another jurisdiction. In both instances, there are compliance and administration costs associated with the need to identify offsetting positions in a foreign jurisdiction. Foreign-information reporting requirements are obviously needed to ensure appropriate enforcement of the loss limitation.

\section{Limited Application of Anti-Tax-Avoidance Rules and/or Doctrines}

In the absence of some form of targeted loss limitation, risk-transfer transactions can be used to transfer market risk to government through the income tax system. In this legislative environment, the principal tax constraint on such transactions for some corporate taxpayers is the binding nature of generalised loss limitations applicable to non-capital losses. Anti-tax-avoidance rules and/or doctrines are ineffective to address a broad range of risk-transfer transactions. The ineffectiveness is attributable to the standard requirement that a particular transaction must be implemented with the purpose of providing a tax benefit narrowly construed as "a reduction, avoidance or deferral of tax payable."71 The transfer of market risk to government through the income tax system realised by risk-transfer transactions generally does not fit readily within this requirement. Although the deductibility of a loss realised on one of the positions constituting a risk-transfer transaction can be considered a tax benefit narrowly construed, the transaction will inevitably fail the required purpose condition. In particular, a taxpayer implementing a risk-transfer transaction is indifferent to the direction of price movements on the underlying market risk such that the location of gain and loss on the relevant positions is irrelevant to the effectiveness of the transaction. This indifference to the location of offsetting gain and loss makes it difficult to conclude that the transaction was entered into for the purpose of accessing a loss deduction.

As illustrated by the transactions in examples 1 and 2 (and perhaps example 3), a risktransfer transaction can be structured to provide a financial benefit in addition to a tax-effective hedge. But again, without any directional bias in the price movements of the underlying market risk, it is difficult to conclude that the particular transaction was entered into to provide a tax benefit in the form of a loss deduction. This leaves

70 Acting unilaterally in adopting a binding loss limitation would be problematic if it were to cause risk-transfer transactions to migrate to other jurisdictions without a loss limitation and such migration resulted in pooling of correlated risks in a smaller number of jurisdictions.

71 See Hollis, supra note 30, at 446 ("Such transactions [risk-transfer transactions] do not obviously constitute 'avoidance': the Exchequer suffers a loss of revenue if exchange rates move in one direction; equally, however, it benefits if they move in the other."). 
the application of anti-tax-avoidance rules and/or doctrines to a limited range of taxdriven transactions that are, in fact, structured such that there is a directional bias locating deductible loss in a tax-effective manner or, alternatively, that are structured to provide a tax benefit in some other form. We highlight in this part of the paper the limited range of risk-transfer transactions entered into with the purpose of providing a tax benefit narrowly construed as "a reduction, avoidance, or deferral of tax or other amount payable ... or an increase in a refund of tax or other amount payable ... 72 Application of anti-tax-avoidance rules and/or doctrines to deny the benefit associated with this limited range of risk-transfer transactions in no way focuses on the transfer of risk that is the result of the scaling of offsetting positions. Any resultant denial of loss recognition must be predicated instead on the presence of a tax benefit narrowly construed that is the dominant purpose of the transaction.

This limited nature of the possible application of anti-tax-avoidance rules and/or doctrines to this subset of risk-transfer transactions is evident in TD 2010/12. We first describe below two examples of risk-transfer transactions entered into for the purpose of providing a tax benefit. The description of these illustrative transactions is followed by a review of the analysis in TD 2010/12 supporting the application of Part IVA to the asymmetric swap in example 3. We suggest that this application requires a factual finding that the structuring of the relevant transaction is such that there is a directional bias in the price movement of the underlying market risk such that realised loss is deductible at a higher tax rate and realised gain on the offsetting position is taxed at a lower rate. The target ineffectiveness of anti-tax-avoidance rules and/or doctrines as a generalised response to risk-transfer transactions is thus relatively obvious. Adoption of a broad loss limitation targeting a wide range of risk-transfer transactions can address many, but not necessarily all, of those transactions entered into with the dominant purpose of providing a tax benefit. With either an anti-taxavoidance rule or a loss limitation rule, tax administrators must find factually that the component parts of a composite transaction are sufficiently linked to be treated as a single transaction. That is, of course, the only feature that these legislative responses share.

\section{A Tri-party Residual Market Risk Swap/Constructive Sale}

\section{Example 10}

Bankco owns a block of 1 million shares of a venture start-up company currently trading at \$17 per share. To hedge a large accrued gain on the shares, Bankco enters into a "Tri-party Residual Market Risk Swap" under which: (i) a subsidiary of Bankco (Subco 1) enters into a prepaid, cash-settled forward contract with an unrelated hedge fund to sell 1.67 million of the shares of the venture start-up company; and (ii) a subsidiary of Bankco (Subco 2) enters into a forward contract with the hedge fund to

72 Income Tax Act (Canada), RSC, 1985, c. 1 (as amended), subsection 245(1) definition of a "tax benefit." See, in this respect, Australian Treasury Department, Improving the Operation of the Anti-Avoidance Provisions in the Income Tax Law (Canberra: Commonwealth of Australia, Discussion Paper, November 2010), at 5-8. 
purchase 1.67 million shares of the venture start-up company. Subco 1 is resident in foreign country A and is subject to a 10 percent tax rate. Subco 2 is resident in foreign country $\mathrm{B}$ and is subject to a 45 percent tax rate. Bankco is subject to a 41.5 percent tax rate in its country of residence.

\section{Figure 4}

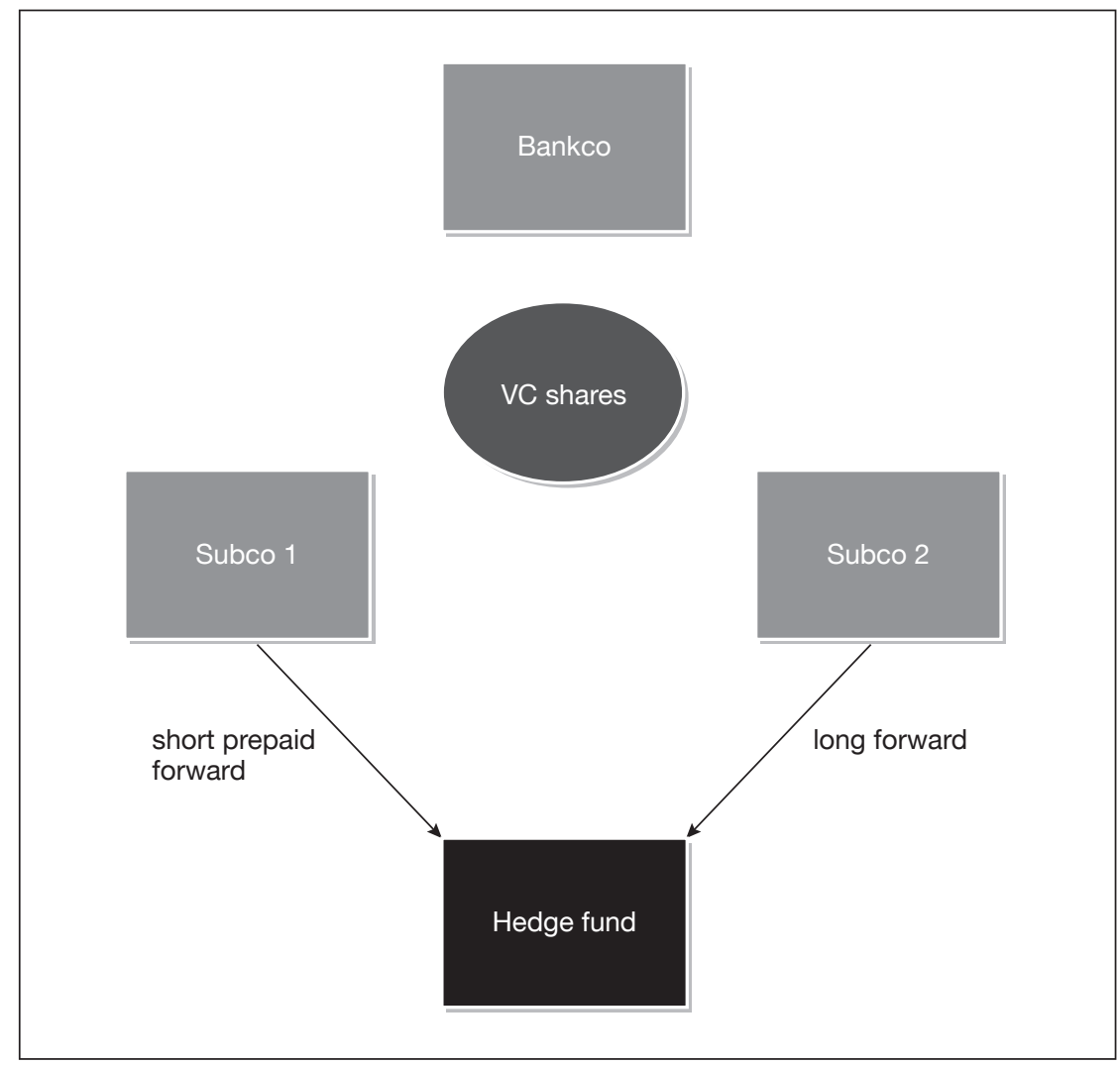

The transaction in example 10 is a "constructive sale" or "monetisation transaction" whereby Bankco eliminates all exposure to future movements in the price of the block of shares it owns while locking in the accrued gain. As a matter of legal form, however, Bankco does not sell the shares and, in the absence of a targeted constructive sale rule ${ }^{73}$ may be able to defer tax payable that would otherwise arise on a transfer of the ownership of the shares as a disposition. More particularly, the combination

73 See, for example, IRC, section 1259; and ITAA, 1997, Draft Subdivision 230-J-Special integrity measures (deemed disposal). See also Anschutz Co. v CIR, 664 F. 3d 313, 2011 (10 ${ }^{\text {th }}$ Cir.); aff'g 135 TC 78, 2010 (TC) (shares subject to variable prepaid forward contract considered to be 
of the short prepaid forward contract and the long forward eliminates all exposure of Bankco to unexpected gain or loss on its ownership of the block of shares of the venture start-up company. This result is realised by constructing the hedge on an aftertax basis using the two subsidiaries subject to different tax rates, rather than Bankco entering into a forward sale of the shares that would eliminate unexpected gain or loss on a pre-tax basis. In this respect, the transaction in example 10 is a risk-transfer transaction comparable to the foreign-currency hedges in examples 1 and 2 and the asymmetric swap in example 3 . Risk associated with the long position in the shares of the venture start-up company is effectively transferred to the three tax jurisdictions in which Bankco and the subsidiaries are resident as a function of the difference in tax rates and scaling of the offsetting positions. Given the specified tax rates in the three tax jurisdictions, the number of shares over which the scaled offsetting forward contracts are written can be determined as follows:

Let $\mathrm{X}=$ the number of shares held by Bankco

Let $\mathrm{Y}=$ the number of shares over which the forward contracts are to be written

therefore $(\mathrm{X}-0.415 \mathrm{X})+(\mathrm{Y}-0.45 \mathrm{Y})=(\mathrm{Y}-0.10 \mathrm{Y})$

and solving for $\mathrm{Y}$

$0.585 \mathrm{X}+0.55 \mathrm{Y}=0.9 \mathrm{Y}$

$0.585 \mathrm{X}=0.9 \mathrm{Y}-0.55 \mathrm{Y}$

$0.585 \mathrm{X}=0.35 \mathrm{Y}$

$0.585 / 0.35 \mathrm{X}=\mathrm{Y}$

$1.67 \mathrm{X}=\mathrm{Y}$

The after-tax positions of Bankco, Subcol and Subco2 are summarised in table 12, along with the tax payable in each of the three jurisdictions and the net tax payable by the corporate group. On a consolidated basis, tax-driven scaling of the respective share positions ensures that gain and loss attributable to subsequent movements in the price of the shares offsets perfectly after tax. Net tax payable for the corporate group equals the gain or loss on the shares owned by Bankco attributable to the same price movements. Risk associated with the ownership of the shares is thereby transferred to the respective governments. The particular allocation of the revenue amounts among the three tax jurisdictions, and the particular allocation of the risk, depends on the particular movement in the price of the shares.

disposed of under a "benefit and burden" analysis of ownership where the taxpayer provided a securities lending facility to the long forward counterparty enabling a short sale of the shares to hedge its long position). 
Table 12

\begin{tabular}{|c|c|c|c|c|c|c|c|c|}
\hline $\begin{array}{l}\text { Rise/fall value } \\
\text { of shares }\end{array}$ & $-100 \%$ & $-75 \%$ & $-50 \%$ & $-25 \%$ & $25 \%$ & $50 \%$ & $75 \%$ & $100 \%$ \\
\hline Bankco & (17) & (12.75) & $(8.50)$ & $(4.25)$ & 4.25 & 8.50 & 12.75 & 17 \\
\hline Tax payable & (7.06) & (5.29) & (3.53) & $(1.76)$ & 1.76 & 3.53 & 5.29 & 7.06 \\
\hline After-tax & $(9.94)$ & $(7.46)$ & $(4.97)$ & $(2.49)$ & 2.49 & 4.97 & 7.46 & 9.94 \\
\hline $\begin{array}{l}\text { Short forward: } \\
\text { Subco1 }\end{array}$ & 28.39 & 21.29 & 14.19 & 7.10 & (7.10) & $(14.19)$ & (21.29) & (28.39) \\
\hline Tax payable & 2.84 & 2.13 & 1.42 & 0.71 & $(0.71)$ & (1.42) & (2.13) & $(2.84)$ \\
\hline After-tax & 25.55 & 19.16 & 12.77 & 6.39 & (6.39) & $(12.77)$ & $(19.16)$ & (25.55) \\
\hline $\begin{array}{l}\text { Long forward: } \\
\text { Subco2 }\end{array}$ & (28.39) & $(21.29)$ & (14.19) & $(7.10)$ & 7.10 & 14.19 & 21.29 & 28.39 \\
\hline Tax payable & $(12.78)$ & $(9.58)$ & (6.39) & $(3.20)$ & 3.20 & 6.39 & 9.58 & 12.78 \\
\hline After-tax & $(15.61)$ & $(11.71)$ & $(7.8)$ & $(3.90)$ & 3.90 & 7.8 & 11.71 & 15.61 \\
\hline $\begin{array}{l}\text { Consolidated } \\
\text { after-tax position }\end{array}$ & 0 & 0 & 0 & 0 & 0 & 0 & 0 & 0 \\
\hline Net tax payable & (17) & (12.75) & $(8.50)$ & $(4.25)$ & 4.25 & 8.50 & 12.75 & 17 \\
\hline
\end{tabular}

This ability to economically dispose of the shares without a disposition for tax purposes is clearly a tax benefit in the form of a deferral of tax payable, and antitax-avoidance rules and/or doctrines could be applied to deny the benefit where the transaction can be identified and can be characterised as implemented to access the deferral. In general, this requires a factual finding that the different components in the transactions are linked in a way that they can be characterised as a composite transaction undertaken to provide the tax deferral. For example, as already noted, the transaction may be structured to avoid realisation-based recognition of gain defined in terms of a formal sale as a matter of non-tax law, or to avoid the application of a constructive sale rule that otherwise extends the concept of a realisation event beyond a formal sale, but is based on the existence of offsetting pre-tax rather than aftertax cash flows. The constructive sale may be undertaken, however, not to defer tax payable on accrued gain, but rather to avoid regulatory or other non-tax restrictions on any sale of the shares. Where the transaction is tax-motivated, general anti-taxavoidance rules and/or doctrines are required to address it in the country of residence of Bankco. A loss limitation rule applicable to risk-transfer transactions more broadly would have no impact because of the location of both offsetting gain and loss in another tax jurisdiction. 


\section{B Loss Freshening/Loss Transfer}

\section{Example 11}

Profitco enters into a swap ("the short swap") with offshore bank whereby Profitco will receive the percentage decrease in value and must pay the percentage increase in value of a $\$ 675 \mathrm{~m}$ notional amount of a specified equity index. At the same time, Loss Sub, a wholly-owned subsidiary of Profitco, enters into a swap ("the long swap") with offshore bank whereby Loss Sub will receive the percentage increase in value and must pay the percentage decrease in value of a $\$ 472.50 \mathrm{~m}$ notional amount of the same specified equity index. Profitco is subject to a 30 percent tax rate. Loss Sub is subject to a 10 percent tax rate but has a substantial amount of loss carryforwards which make it effectively non-taxable.

\section{Figure 5}

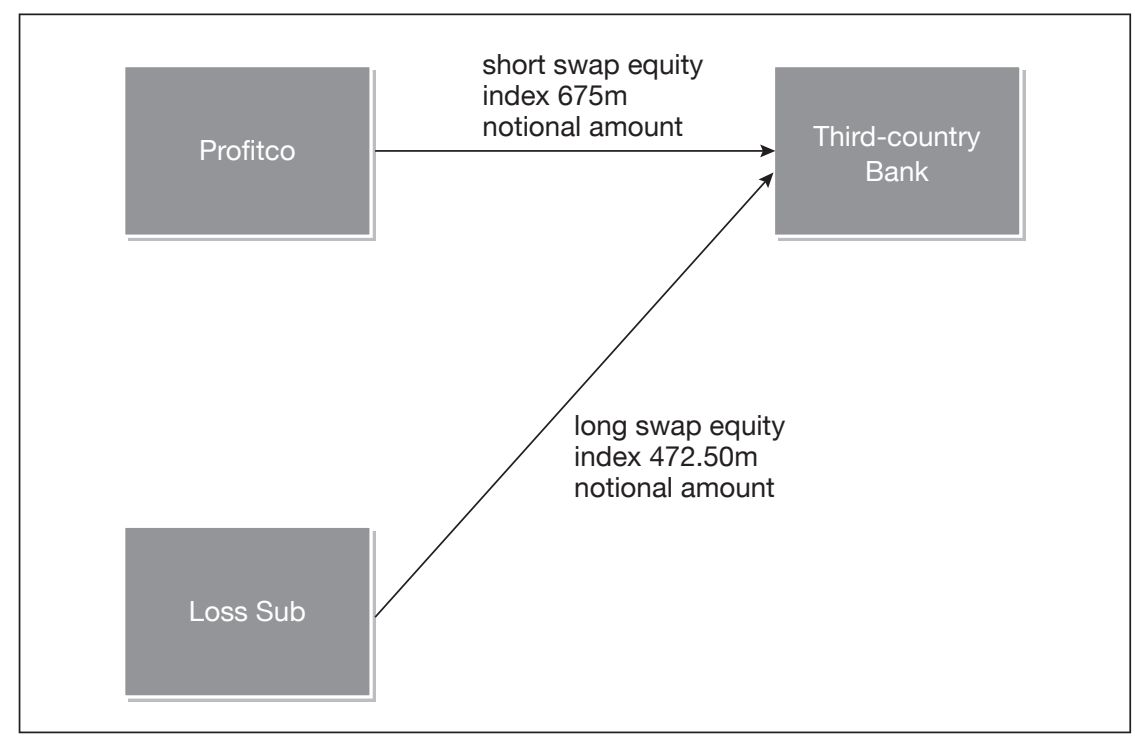

The risk-transfer transaction in example 11 uses an asymmetric swap similar to that in example 3 to refresh expiring loss carryovers and transfer them cross-border. ${ }^{74}$ Loss Sub uses its loss carryovers against any realised gain on the long swap and transfers a portion of those carryovers to Profitco in the form of a realised loss on the short swap. This result occurs provided that the equity price index appreciates so that Profitco realises loss on the short swap and Loss Sub realises gain on the long swap. As summarised in table 13, the net pre-tax exposure to the equity index in example 11 is $\$ 202.50 \mathrm{~m}$, but the position of Profitco is scaled such that the after-tax cash flows

74 See Corporate Loss Utilisation, supra note 4, at 51-52. 
offset on a consolidated basis. Because Profitco has entered into the offsetting short swap, appreciation in the index results in a realised loss that is offset on an after-tax basis with a gain realised by Loss Sub. Loss carryovers available to Loss Sub provide an effective non-taxable status such that its long swap is not scaled to account for a positive tax rate. Any gain realised on this position is offset with the loss carryovers, while effectively transferring a portion of those losses to Profitco on its offsetting short position. If the equity index declines in value, Profitco will realise gain on the short position which is offset on an after-tax basis with realised loss on the long position held by Loss Sub. The effective non-taxable position of Loss Sub means that the pretax amount of the realised loss equals the after-tax amount.

\section{Table 13}

\begin{tabular}{|c|c|c|c|c|c|c|c|c|}
\hline $\begin{array}{l}\text { Rise/fall } \\
\text { value of } \\
\text { equity } \\
\text { index }\end{array}$ & $-100 \%$ & $-75 \%$ & $-50 \%$ & $-25 \%$ & $25 \%$ & $50 \%$ & $75 \%$ & $100 \%$ \\
\hline $\begin{array}{l}\text { Short swap: } \\
\text { Profitco }\end{array}$ & 675 & 506.25 & 337.50 & 168.75 & (168.75) & (337.50) & (506.25) & (675) \\
\hline Tax payable & 202.50 & 151.88 & 101.25 & 50.62 & (50.62) & (101.25) & (151.88) & (202.50) \\
\hline After-tax & 472.50 & 354.37 & 236.25 & 118.13 & $(118.13)$ & (236.25) & (354.37) & $(472.50)$ \\
\hline $\begin{array}{l}\text { Long swap: } \\
\text { Loss Sub }\end{array}$ & \begin{tabular}{|l|}
$(472.50)$ \\
\end{tabular} & \begin{tabular}{|l|}
$(354.37)$ \\
\end{tabular} & \begin{tabular}{|l|}
$(236.25)$ \\
\end{tabular} & (118.13) & 118.13 & 236.25 & 354.37 & 472.50 \\
\hline Tax payable & 0 & 0 & 0 & 0 & 0 & 0 & 0 & 0 \\
\hline After-tax & (472.50) & (354.37) & (236.25) & $(118.13)$ & 118.13 & 236.25 & 354.37 & 472.50 \\
\hline $\begin{array}{l}\text { Consolidated } \\
\text { position }\end{array}$ & 0 & 0 & 0 & 0 & 0 & 0 & 0 & 0 \\
\hline
\end{tabular}

This ability to refresh the loss carryovers of Loss Sub and transfer them cross-border to Profitco is clearly a tax benefit in the form of the loss deduction, and anti-taxavoidance rules and/or doctrines could be applied to deny the benefit where the transaction can be characterised as implemented to provide the deduction. As with the constructive sale in example 10, this requires a factual finding that the different components in the transactions are connected in a way that they can be characterised as a composite transaction undertaken to provide a tax benefit - in this case, the loss deduction by Profitco. It also requires a factual finding that the transaction is priced off-market in such a way that there is a directional bias in the movements of the underlying equity index that ensures loss is realised on the short swap by Profitco and offsetting gain is realised by Loss Sub on the long swap. For example, the transaction could be characterised as a non-tax driven hedge, with transfer of risk through the income tax system, if the realistically expected bounds of subsequent movements in 
the equity price index extended to declines such that loss would be realised by Loss Sub and gain by Profitco.

In contrast with the constructive sale in example 10, a broad loss limitation targeting risk-transfer transactions could ensure that the loss transfer transaction in example 11 is ineffective, whether or not it is structured to provide a tax benefit in the form of the location of the loss deduction in Profitco. Such a rule would equally apply to deny loss recognition to a risk-transfer transaction that is a tax-driven loss transfer or a risk-transfer transaction in which the taxpayers transfer risk through the income tax system but are indifferent as to where gain or loss is located. In the latter instance, the transaction would be priced on-market which would mean that there should be no directional bias in price movements of the underlying equity index.

\section{Asymmetric Swap with a Drift Adjustment - TD 2010/12}

Where the tax benefit associated with a risk-transfer transaction is a loss deduction, the significance of a factual finding that its location is predetermined because of a directional bias is evident in TD 2010/12. In this respect, the asymmetric swap that is the subject of the taxation determination is similar to that in example 11, but with an additional feature referred to as "the drift adjustment." In fact, the taxation determination identifies two possible tax benefits:

- $\quad$ the deduction of the amount of the drift adjustment by resident bank; and

- $\quad$ the deduction of realised loss on the long swap position by resident bank.

Nonetheless, as with the transaction in example 11, the finding of a tax benefit and a dominant purpose to access that benefit depends critically on a factual finding that the swap is structured such that loss is, more likely than not, to arise in the highertaxed DBU, while gain arises in the lower-taxed OBU. The location of loss and gain in this way occurs provided that the equity index moves within expected bounds. The presence of the drift adjustment does nothing more than amplify the expected amounts within these expected bounds. Risk is thus transferred to government through the income tax system with the additional benefit of a tax benefit in the form of location of the loss side of the transaction in the higher-taxed member of the corporate group.

There is considerable discussion in TD2010/12 of the characterisation of the asymmetric swap as a "scheme" for the purpose of Part IVA: that is, a composite transaction sufficiently linked to be treated as a single transaction. Although this characterisation is not without its own difficulties in the application of a general anti-tax-avoidance rule or a broad loss limitation of the type we suggest, we prefer to focus on what we believe is the more conceptually problematic aspect of the taxation determination for the point we want to make in this part of the article: that is, the finding that the asymmetric swap was entered into with the dominant purpose of providing a tax benefit. It is this requirement that limits considerably the 
relevance of general anti-tax-avoidance rules and/or doctrines as a response to risktransfer transactions and that is especially problematic in the context of the taxation determination.

As noted already, TD 2010/12 posits both a wide and a narrow interpretation of the concept of a tax benefit in the context of the asymmetric swap. The narrow interpretation focuses on the presence of the drift adjustment. In essence, this added feature is intended to replicate the cash flows associated with a total-return equity swap and, in effect, provide a measure of market neutrality that would otherwise be reflected in the forward price of the relevant index. In particular, futures parity, as an arbitrage pricing relationship, posits that the forward price of an asset is a function of the spot price and the cost of carry less any expected returns on the asset. ${ }^{75}$ Accordingly, market neutrality is realised in the sense that the price of a current or deferred purchase of an asset is equivalent and there are no arbitrage opportunities. With an equity swap, the same result is realised by the long equity receiver paying the short equity payer an interest amount determined as a percentage of the notional principal, and the short equity payer paying the long equity receiver any dividends received on the notional amount of the basket of shares that are the subject of the swap. The long equity receiver receives an amount equal to any appreciation in value of the referenced shares over the term of the swap, and the short equity payer receives an amount equal to the decline in value of the referenced shares over the term of the swap.

This same feature is replicated with the asymmetric swap that is the subject of TD 2010/12 by having the resident bank effectively pay the non-resident bank, in the form of an adjustment to their respective obligations, a fixed percentage of the net

75 This relationship between spot and forward prices can be seen most obviously when it is recognised that the prospective purchaser of an asset has a simple choice: purchase the asset now at its spot price or take future delivery at the forward price. In either case, the purchaser will acquire the same asset but with two important differences that together determine the forward price. First, because a forward purchaser does not take immediate delivery, he has the use of the funds that would have been required to purchase the asset at its spot price and can earn a return on those funds. Second, the forward purchaser forgoes any return on the asset in the period before purchase. Arbitrage trading ensures that there is no difference in the return available from the purchase of an asset immediately at its spot price and its acquisition at some time in the future at a forward price. Accordingly, the forward price of an asset is a function of the spot price multiplied by the implicit cost of carry (or the riskless rate of return that the forward purchaser can earn) less the expected amount of the return on a long position in the asset. This relationship can be expressed as:

forward price $=$ spot price $\mathrm{x}(1+\mathrm{r} f)^{\mathrm{t}} /(1+\mathrm{r} p v)^{\mathrm{t}}$

where $r$ is the riskless interest rate for the term of the forward contract represented by $\mathrm{t}$ and $\mathrm{r} p v$ is the present value of the return on an asset forgone by a forward purchaser.

The relationship between spot and forward prices for commodities is complicated by the fact that the forward purchaser does not incur storage costs but forgoes the convenience yield from actually possessing the commodity. These two factors must also be accounted for in determining the forward price. 
long exposure to the equity index, presumably determined as the cost of carry of the notional amount of the index less any expected dividends on the relevant shares. But rather than have the amount determined as a fixed percentage of the net long exposure, it is determined by netting out a fixed percentage amount on the short swap and a fixed percentage amount on the long swap. Because of scaling of the offsetting positions, this pricing form ensures that the drift adjustment is effectively paid by government through the income tax system. Assume, for example, that an equity receiver would be required to pay 5 percent of any long position. The resident bank in example 3 would therefore have to pay the non-resident bank $7.5 \mathrm{~m}$ over the term of the swap, which is 5 percent of the net long exposure to the specified equity index of $150 \mathrm{~m}$ under the asymmetric swap. This result is realised, however, by resident bank paying $33.75 \mathrm{~m}$, which is 5 percent of the $675 \mathrm{~m}$ notional amount of the long swap, and by non-resident bank paying $26.25 \mathrm{~m}$, which is 5 percent of the $525 \mathrm{~m}$ notional amount of the short swap. Netting the two amounts, resident bank pays non-resident bank $7.5 \mathrm{~m}$ over the term of the swap. This result, under various movements in the equity index, is summarised in table 14.1. The opposite net position of non-resident bank is summarised in table 14.2. The position of government is summarised in table 14.3 where it can be seen that the drift adjustment, as well as the risk associated with the net long position assumed by resident bank, is transferred through the income tax system.

\section{Table 14.1: Resident Bank}

\begin{tabular}{|c|c|c|c|c|c|c|c|c|}
\hline $\begin{array}{l}\text { Rise/fall } \\
\text { value of } \\
\text { equity index }\end{array}$ & $-100 \%$ & $-75 \%$ & $-50 \%$ & $-25 \%$ & $25 \%$ & $50 \%$ & $75 \%$ & $100 \%$ \\
\hline $\begin{array}{l}\text { Short swap } \\
525 \mathrm{~m}\end{array}$ & 525 & 393.75 & 262.50 & 131.25 & (131.25) & (262.50) & (393.75) & (525) \\
\hline Drift adjustment & 26.25 & 26.25 & 26.25 & 26.25 & 26.25 & 26.25 & 26.25 & 26.25 \\
\hline Net gain/loss & 551.25 & 420 & 288.75 & 157.50 & (105) & (236.25) & (367.50) & $(498.75)$ \\
\hline $\begin{array}{l}\text { Tax payable } \\
\text { @ 10\% }\end{array}$ & 55.13 & 42 & 28.88 & 15.75 & $(10.50)$ & (23.63) & (36.75) & $(49.88)$ \\
\hline After-tax & 496.12 & 378 & 259.87 & 141.75 & $(94.50)$ & (212.62) & (330.75) & $(448.87)$ \\
\hline $\begin{array}{l}\text { Long swap } \\
675 \mathrm{~m}\end{array}$ & (675) & (506.25) & $(337.50)$ & (168.75) & 168.75 & 337.50 & 506.25 & 675 \\
\hline Drift adjustment & (33.75) & (33.75) & (33.75) & (33.75) & (33.75) & (33.75) & (33.75) & (33.75) \\
\hline Net gain/loss & (708.75) & (540) & (371.25) & (202.50) & 135 & 303.75 & 472.50 & 641.25 \\
\hline $\begin{array}{l}\text { Tax payable } \\
\text { @30\% } \\
\end{array}$ & (212.63) & (162) & (111.38) & \begin{tabular}{|l|}
$(60.75)$ \\
\end{tabular} & 40.50 & 91.13 & 141.75 & 192.38 \\
\hline After-tax & (496.12) & (378) & $(259.87)$ & (141.75) & 94.50 & 212.62 & 330.75 & 448.87 \\
\hline
\end{tabular}




\begin{tabular}{l|l|l|l|l|l|l|l|l}
\hline $\begin{array}{l}\text { Consolidated } \\
\text { position }\end{array}$ & 0 & 0 & 0 & 0 & 0 & 0 & 0 & 0 \\
\hline
\end{tabular}

\section{Table 14.2: Non-resident Bank}

\begin{tabular}{|c|c|c|c|c|c|c|c|c|}
\hline $\begin{array}{l}\text { Rise/fall value } \\
\text { of equity } \\
\text { index }\end{array}$ & $-100 \%$ & $-75 \%$ & $-50 \%$ & $-25 \%$ & $25 \%$ & $50 \%$ & $75 \%$ & $100 \%$ \\
\hline $\begin{array}{l}\text { Long position: } \\
150 \mathrm{~m}\end{array}$ & (150) & (112.50) & (75) & $(37.50)$ & 37.50 & 75 & 112.50 & 150 \\
\hline $\begin{array}{l}\text { Long swap: } \\
525 \mathrm{~m}\end{array}$ & (525) & (393.75) & (262.50) & (131.25) & 131.25 & 262.50 & 393.75 & 525 \\
\hline Drift adjustment & (26.25) & (26.25) & $(26.25)$ & $(26.25)$ & $(26.25)$ & $(26.25)$ & $(26.25)$ & $(26.25)$ \\
\hline $\begin{array}{l}\text { Short swap: } \\
675 \mathrm{~m}\end{array}$ & 675 & 506.25 & 337.50 & 168.75 & (168.75) & (337.50) & $(506.25)$ & (675) \\
\hline Drift adjustment & 33.75 & 33.75 & 33.75 & 33.75 & 33.75 & 33.75 & 33.75 & 33.75 \\
\hline Net position & 7.50 & 7.50 & 7.50 & 7.50 & 7.50 & 7.50 & 7.50 & 7.50 \\
\hline
\end{tabular}

Table 14.3: Government Revenue

\begin{tabular}{|c|c|c|c|c|c|c|c|c|}
\hline $\begin{array}{l}\text { Rise/fall value } \\
\text { of equity index }\end{array}$ & $-100 \%$ & $-75 \%$ & $-50 \%$ & $-25 \%$ & $25 \%$ & $\mathbf{5 0 \%}$ & $75 \%$ & $100 \%$ \\
\hline $\begin{array}{l}\text { Short swap: tax } \\
\text { with drift }\end{array}$ & 55.13 & 42 & 28.88 & 15.75 & (10.50) & (23.63) & (36.75) & (49.88) \\
\hline $\begin{array}{l}\text { Long swap: tax } \\
\text { with drift }\end{array}$ & (212.63) & (162) & (111.38) & $(60.75)$ & 40.50 & 91.13 & 141.75 & 192.38 \\
\hline Net tax with drift & (157.50) & (120) & (82.50) & (45) & 30 & 67.50 & 105 & 142.50 \\
\hline $\begin{array}{l}\text { Net tax } \\
\text { without drift }\end{array}$ & (150) & (112.50) & (75) & (37.50) & 37.50 & 75 & 112.50 & 150 \\
\hline
\end{tabular}


We have argued that the transfer of risk to government through the income tax system, which is the result of scaling of offsetting positions, presents a policy problem that requires a targeted response. The transfer of payment of the drift adjustment through the income tax system using the same technique is conceptually similar and also requires a targeted response in the form of a loss limitation. But unless it can be concluded that the pricing of the swap is off-market such that the realised loss is located in the higher-taxed DBU of the resident bank, it is difficult to conclude that the swap is entered into with the dominant purpose of providing a tax benefit, narrowly construed, and defined for the purpose of Part IVA as an "amount that is not assessable if it would have been assessable if the scheme had not been entered into, or a deduction that is allowable to a taxpayer in a taxation year if the deduction would not have been available if the scheme had not been entered into."76

More particularly, the asymmetric swap could be considered to be entered into for the dominant purpose of obtaining a tax benefit in the form of a deductible loss only if it is reasonably certain that the loss is isolated in the higher-taxed resident bank's $\mathrm{DBU}$ and the offsetting gain is isolated in the lower-taxed OBU. This result can be realised only if the forward price embedded in the transaction, or the drift adjustment as a proxy for such a price, is off market. Otherwise, there would be no directional bias that would support a conclusion that loss and gain are allocated in a way that the transaction could be considered to be entered into to generate loss in a taxadvantageous manner. Yet TD2010/12 strains to characterise the location of income deductions, both realised loss and the drift adjustment, in a tax-driven manner as between the higher-taxed resident bank's DBU and the lower-taxed OBU.

At paragraph 47 of TD 2010/12, the Commissioner expresses the view that: "A simple approach may be to identify the drift adjustment as the tax benefit because it is a fixed and determined amount that is agreed upfront." In this regard, the taxation determination states that, regardless of the way the index moves, the drift adjustment causes the assessable income of the resident bank to be lower, or the allowable deductions to be higher by the amount of the drift adjustment. This is certainly correct and can be seen in table 14.3 by comparing the net tax with and without the drift adjustment. Irrespective of movements in the equity index, net tax payable is either $7.50 \mathrm{~m}$ less or the tax saving is $7.50 \mathrm{~m}$ greater with the drift adjustment. However, this would be entirely the same result if, instead of the drift adjustment, the offsetting positions were priced on the basis of on-market forward prices. ${ }^{77}$ Indeed, if the amount of the drift adjustment is on-market in the sense that it is a reflection of forward prices, net tax payable summarised in table 14.3 would be exactly the same as it is with the drift adjustment. This result is summarised in table 14.4 where it is

76 ITAA 1997, section 177C.

77 See, in this respect, Aggressive Tax Planning based on After-Tax Hedging, supra note 4, at 27 (observing that the effect of an asymmetric swap with a drift adjustment can be replicated as an investment in shares with a value linked to a benchmark index, with the benchmark index also being the object of a forward purchase agreement with an over-hedge). 
assumed that the on-market forward price of the index equals the current spot price (525m short position and $675 \mathrm{~m}$ long position) plus five percent.

Table 14.4

\begin{tabular}{|c|c|c|c|c|c|c|c|c|}
\hline $\begin{array}{l}\text { Rise/fall } \\
\text { value of } \\
\text { equity index }\end{array}$ & $-100 \%$ & $-75 \%$ & $-50 \%$ & $-25 \%$ & $25 \%$ & $50 \%$ & $75 \%$ & $100 \%$ \\
\hline \multicolumn{9}{|l|}{$\begin{array}{l}\text { Short forward } \\
551.25 \mathrm{~m}\end{array}$} \\
\hline Net gain/loss & 551.25 & 420 & 288.75 & 157.50 & (105) & (236.25) & $(367.50)$ & (498.75) \\
\hline $\begin{array}{l}\text { Tax payable } \\
@ 10 \%\end{array}$ & 55.13 & 42 & 28.88 & 15.75 & (10.50) & (23.63) & (36.75) & (49.88) \\
\hline After-tax & 496.12 & 378 & 259.87 & 141.75 & $(94.50)$ & $(212.62)$ & (330.75) & $(448.87)$ \\
\hline \multicolumn{9}{|l|}{$\begin{array}{l}\text { Long swap } \\
708.75 \mathrm{~m}\end{array}$} \\
\hline Net gain/loss & $(708.75)$ & (540) & (371.25) & (202.50) & 135 & 303.75 & 472.50 & 641.25 \\
\hline $\begin{array}{l}\text { Tax payable } \\
\text { @30\% }\end{array}$ & (212.63) & (162) & (111.38) & $(60.75)$ & 40.50 & 91.13 & 141.75 & 192.38 \\
\hline After-tax & $(496.12)$ & (378) & $(259.87)$ & (141.75) & 94.50 & 212.62 & 330.75 & 448.87 \\
\hline $\begin{array}{l}\text { Consolidated } \\
\text { position }\end{array}$ & 0 & 0 & 0 & 0 & 0 & 0 & 0 & 0 \\
\hline Net tax payable & $(157.50)$ & $(120)$ & $(82.50)$ & (45) & 30 & 67.50 & 105 & 142.50 \\
\hline
\end{tabular}

It is difficult to conclude, therefore, that the location of the drift adjustment as a deductible amount is tax-driven. This conclusion could only be reached if it could be determined factually that the pricing of the transaction - either in the form of forward prices or spot prices plus the drift adjustment - was off-market and thereby amplified the deduction for the resident bank's DBU. In this case, Part IVA could be applied to deny the deduction of loss attributable to the drift adjustment. The taxation determination appears to acknowledge this proposition at paragraph 27 where it is stated that: "... it has been suggested the drift adjustment ensures that when the swaps are entered into, there is a neutral expectation of the value of the benchmark index rising or falling over the term of the swap by removing any bias for profits to accrue in either the Australian resident company's DBU or its OBU." But the non-tax significance of the drift adjustment is apparently denied when this statement is followed by the proposition in paragraph 28 that: "At day 1 of the swap the shares that comprise the index will have a market price. The past performance of the shares is already embedded in their market price." This statement simply ignores 
the arbitrage pricing relationship that is the basis of forward prices, with the use of the drift adjustment as a proxy for such prices. $^{78}$

At paragraphs 48 to 50 , the taxation determination expands on what it considers to be a tax benefit when it is concluded that any deduction that arises because of the net swap position is a tax benefit: that is, whenever the increase in the index is less than the drift percentage of 5 percent, or there is a decrease in the index, there would be a net tax benefit because a net loss is generated. On this characterisation of the asymmetric swap, the entire amount of any deductible loss, and not just the drift adjustment, would be denied. Although somewhat unclear, the apparent reasoning for this wider interpretation is that the asymmetric swap is a structured transaction that, for the following reasons, is priced off-market ${ }^{79}$ and is therefore not part of a broader scheme:

- a reasonable person might expect that if the scheme had not been entered into or carried out, no similar transaction, or perhaps any transaction, would have been entered into or carried out;

- $\quad$ one would not expect the parties to enter into an asymmetric swap which lacked the drift adjustment;

- $\quad$ without the drift adjustment, the payment of the fees at non-commercial rates would not be possible; and

- $\quad$ without the drift adjustment, the non-resident counterparty could not have obtained the net short exposure to the index at the non-arms length price obtained in the asymmetric swap scheme.

Again, these stated reasons appear to ignore the use of the drift adjustment as a proxy for on-market forward prices. Indeed, offsetting forward contracts could be used to realise much the same risk transfer as the asymmetric swap. A net payment would be made between the counterparties only if the forwards were off-market and the payments served to ensure that they are on-market. Moreover, the payment of fees at non-commercial rates could simply be attributable to the fact that the resident bank need not incur the costs to hedge the position it assumes because it has structured the transaction to transfer its exposure through the income tax system. But scaling in that sense does not necessarily support a conclusion that the transaction was entered into with the dominant purpose of providing a tax benefit narrowly construed. That conclusion can only be supported by a drift adjustment that does not reflect on-

78 See, in this respect, Aggressive Tax Planning based on After-Tax Hedging, supra note 4, at 29 ("The purported neutrality of the drift adjustment is artificial, basically, because it would imply that the value at inception of the positions taken by each participant (on a stand-alone basis) should have been determined or evaluated on the basis of a theoretical approach not acceptable or shared in the financial market at arm's length and commonly referred to as the "nonarbitrage theory.").

79 Ibid., at 33 (noting that a transfer-pricing or profit allocation adjustment may be used to address asymmetric swaps that entail deliberate mispricing). 
market forward prices and thereby provides a directional bias to locate deductible loss in the DBU of resident bank.

\section{Conclusion}

Tax policymakers should consider adoption of a generalised loss limitation applicable to risk-transfer transactions involving imperfectly offsetting pre-tax cash flows but perfectly (or near perfectly) offsetting after-tax cash flows. There is no apparent market failure that would suggest government should perform a risk-bearing role in this context; moreover, the performance of that role is entirely random given the necessary requirement that corporate taxpayers do not face otherwise binding loss limitations. Nonetheless, the fragmentary transactional evidence, combined with costliness of the identification exercise associated with a broad loss limitation and perceptions of a negative impact on the decision to hedge, may support adoption of a more narrowly focused loss limitation. In that case, tax policymakers and tax administrators need to distinguish clearly three types of risk-transfer transactions:

- $\quad$ risk-transfer transactions that do not provide a financial benefit other than the transfer of risk to government through the income tax system;

- $\quad$ risk-transfer transactions that provide a financial benefit other than a tax benefit; and

- $\quad$ risk-transfer transactions that provide a tax benefit.

The second type of transaction is the target of the loss limitation recently adopted by UK Inland Revenue; it can be justified to the extent that factors, such as the presence of a financial benefit, can be relied on as proxies for structured risk-transfer transactions which do not entail the same level of identification costs associated with risk-transfer transactions generally. Moreover, given that this subset of transactions are often substituted for hedge transactions that do not transfer risk to government, any negative impact on the decision to hedge may arguably be avoided. But this kind of more limited approach requires that tax administrators use general anti-taxavoidance rules and/or doctrines to address risk-transfer transactions that provide a tax benefit, narrowly construed, and not necessarily a financial benefit. The conceptual difficulties in applying this approach are readily apparent in TD 2010/12. 
